\title{
4-6 Yaş Kur'ân Kursu Öğreticilerine Göre Mahremiyet Eğitimi ve Önemi (Nitel Bir Analiz)
}

\author{
Ramazan Diler \\ Dr. Öğr. Üyesi, Tokat Gaziosmanpaşa Üniversitesi (ROR ID: 01rpe9k96) \\ İslami İlimler Fakültesi, Felsefe ve Din Bilimleri Bölümü \\ Assist. Prof. Dr., Gaziosmanpaşa University, Faculty of Islamic Sciences, Department of Philosophy and \\ Religious Sciences, Tokat/Turkey \\ ramazan.diler@gop.edu.tr ORCID: 0000-0002-8659-0018
}

\section{Privacy Education and Its Importance According to the Qur'an Course Instructors of 4-6 Year-old Pupils (A Qualitative Analysis)}

\begin{abstract}
The Qur'an course is one of the major non-formal education institutions in our country. The primary goals of this institution is to teach the Qur'an and basic religious knowledge to its participants. This institution has expanded its working area in time in accordance with its mission. As a pilot application, Qur'an courses started to accept students in order to provide religious education to pre-school children as of the 2013-2014 academic year. The current Qur'an course teachers undertook the education of children in this period. The courses that accept students in this way are known as Quran courses for ages 4-6. Based on the needs of the children, it is known that different activities take place in the context of values education in the Qur'an courses of ages 4-6. Recently, it has been observed that privacy training is also included in the courses for reasons such as frequent child abuse. However, the privacy education applied in the Quran courses is not directly expressed in the curriculum of the Qur'an course of 4-6 years of age. It can be said that privacy education is a religious, moral and culturally healthy sexual identity development education. Nevertheless, privacy education takes care and protection of the child's own privacy; it is a comprehensive education that includes respecting someone else's private spaces. The aim of this education is to raise children as a healthy individual from an early age. These practices and informations, which aim to make children gain positive qualities and to be sensitive to some negativities, should be considered important.

It is worth exploring what the contribution of privacy education is to the child's upbringing as a healthy individual. Examining the opinions of the instructors about privacy education is considered important for the curriculum development studies. Therefore, the science of religious education should investigate the competencies of the Qur'an course instructors in privacy education. This discipline should investigate teachers' thoughts about privacy; accordingly, they need to analyze and evaluate what kind of privacy education they have developed. In addition, the opinions of the Qur'an course instructors aged 4-6 about the importance of privacy education should be revealed and analyzed. Scientific investigation of these dimensions is thought to
\end{abstract}

Intihal Taraması/Plagiarism Detection: Bu makale intihal taramasından geçirildi/This paper was checked for plagiarism Geliş/Received: 09 Mayıs/May 2020 | Kabul/Accepted: 02 Eylül/July 2020 | Yayın/Published: 20 Eylül/September 2020 Atıf/Cite as: Ramazan Diler, “4-6 Yaş Kur’ân Kursu Öğreticilerine Göre Mahremiyet Eğitimi ve Önemi (Nitel Bir Analiz) = Privacy Education and Its Importance According to Preschool Qur'an Course Instructors (A Qualitative Analysis)”, Eskiyeni 41 (Eylül/September 2020), 623-652. https://doi.org/10.37697/eskiyeni.734877

Copyright @ Anadolu İlahiyat Akademisi/Anatolian Theological Academy, 06050, Ankara, Turkey | www.anilakademi.com CC BY-NC 4.0 | This paper is licensed under a Creative Commons Attribution-NonCommercial License 
make important contributions to curriculum developers and parents, especially those carrying out educational activities in the Qur'an courses. In this study, it was aimed to investigate the knowledge and attitudes of the Qur'an course instructors of 4-6 years of age as an example of a situation in the preschool period about privacy education. Understanding the thoughts of the teachers who carry out studies in an important area and guide learning about privacy education makes the study important. To the other teachers and employees who work in the preschool, especially the instructors of the Qur'an courses of 4-6 years of age of working with this experiment; it is thought that it will provide important contributions to parents, academicians working on privacy education, curriculum developers.

Qualitative research model was preferred in this study. The case study design, one of the qualitative research designs, was chosen for the study. Case study is defined as "an empirical research method that works within a real life framework of a current phenomenon and examines the situations in many ways, systematically and in depth". The sample in the study was determined by the typical case sampling method, which is one of the purposeful sampling methods. Typical case sampling means "selecting individuals who are likely to behave like others". Interview was deemed appropriate as a data collection tool in this study. Interview is one of the most common data collection methods used in research in social sciences. Consequently, interviewing is a very effective method of obtaining information about individuals' experiences, attitudes, opinions, complaints, feelings and beliefs. In the 2019-2020 academic year, 10 Qur'an Course instructors were interviewed in the center of Tokat province. Data obtained through study tools were analyzed with content analysis method. Content analysis is defined as "a systematic, repeatable technique in which some words of a text are summarized with smaller content categories with coding based on certain rules".

Some of the results obtained from the study are as follows; According to the Qur'an course instructors of 4-6 years of age, the concept of privacy has a wide content that can be associated with almost all of the personality, morality, adaptation, religion, society, education, family, school and behaviors in these institutions. There is no common understanding among the Quran course instructors regarding the definition of privacy education. Qur'an course instructors of 4-6 years of age think that there is a relationship between sexual education and privacy education, but privacy education is more comprehensive and more appropriate to meet needs. Instructors thought that privacy education should be directly related to morality and adaptability. In some opinions, it was suggested that training in morality or adaptability might be sufficient for the child's sense of privacy. The tutorials mostly associated privacy education in some way with moral education. This shows that privacy education is understood as a comprehensive moral education. According to the teachers, privacy education is an education that children should definitely take. It was seen that the teachers were in full agreement on this subject. According to the instructors, this education can make a significant contribution to the child, such as knowing and respecting himself and others. Depending on this study, the following suggestions are included; New, different field studies with the theme of privacy education can be carried out for instructors and teachers working in all other institutions, especially pre-school education institutions. This study demonstrated the need for privacy education in pre-service training programs. Therefore, it can be suggested that teachers and instructors working in all levels and institutions of early childhood education should be provided with a planned and scheduled privacy training and included in this education.

\section{Keywords}

Religious Education, Moral Education, Privacy Education, 4-6 Age Qur'an Course, Qur'an Course Instructor 


\section{4-6 Yaş Kur’ân Kursu Öğreticilerine Göre Mahremiyet Eğitimi ve Önemi (Nitel Bir Analiz)}

\section{Öz}

Kur'an kursu ülkemizdeki önemli yaygın eğitim kurumlarındandır. Bu kurumun öncelikli amacı katılımcılarına Kur'an ve temel dini bilgileri öğretmektir. Bu kurum varlık misyonuna uygun olarak çalışma alanını zamanla genişletmiştir. Kur'an kursları, bir pilot uygulama olarak, 2013-2014 öğretim yılından itibaren okul öncesi çocuklarına da din eğitimi vermek amacıyla öğrenci kabul etmeye başlamıştır. Bu dönemdeki çocukların eğitimini mevcut Kur'an kursu öğreticileri üstlenmiştir. Bu şekilde öğrenci kabul eden kurslar "4-6 yaş Kur'an kursları” olarak tanınmaktadır. Çocukların ihtiyaçlarından hareketle, 4-6 yaş Kur'an kurslarında değerler eğitimi bağlamında farklı etkinliklere yer verildiği bilinmektedir. Son dönemlerde, sıç̧a rastlanan çocuk istismarı gibi nedenlerle kurslarda mahremiyet eğitimine de yer verildiği görülmektedir. Ancak Kur’an kurslarında uygulanmakta olan mahremiyet eğitimi, 4-6 yaş Kur'an kursu öğretim programında doğrudan ifade edilmemiştir. Mahremiyet eğitimi çocuğun dini, ahlaki ve kültürel açıdan sağlıklı bir cinsel kimlik geliştirme eğitimidir, denilebilir. Bununla birlikte mahremiyet eğitimi çocuğun kendi özelini önemseme, koruma; başkasının özeline saygı duymayı içeren geniş kapsamlı bir eğitimdir. Bu eğitimin amacı çocukların erken yaşlardan itibaren sağlıklı bir birey olarak yetişmeleridir. Çocukların olumlu nitelikler kazanmaları, bazı olumsuzluklara karşı duyarlı olmalarını amaçlayan bu uygulama ve bilgilendirmeler önemli görülmelidir.

Çocukların sağlıklı bir birey olarak yetişmelerinde mahremiyet eğitiminin katkısının ne olduğu araştırılmaya değerdir. Mahremiyet eğitimine ilişkin öğretici görüşlerinin incelenmesi, öğretim programlarının geliştirilmesi açısından önemli görülmektedir. Bundan dolayı din eğitimi biliminin Kur'an kursu öğreticilerinin mahremiyet eğitimi konusundaki yeterliklerini araştırması gerekir. Bu disiplinin, öğreticilerin mahremiyet hakkındaki düşüncelerinin neler olduğunu; buna bağlı olarak onların nasıl bir mahremiyet eğitimi tanımı geliştirdiklerini analiz edip değerlendirmesi gerekir. Ayrıca 4-6 yaş Kur’an kursu öğreticilerinin mahremiyet eğitiminin önemi hakkındaki düşüncelerinin de ortaya konulup analiz edilmesi gerekmektedir. Bu boyutların bilimsel açıdan araştırılmasının Kur'an kurslarında eğitim faaliyeti yürütenler başta olmak üzere, program geliştiricilere ve velilere önemli katkılar sağlayacağ düşünülmektedir. Bu araştırmada okul öncesi dönemin bir durum örneği olarak 4-6 yaş Kur'an kursu öğreticilerinin mahremiyet eğitimi hakkındaki bilgi ve tutumlarının neliğinin araştırılması amaçlanmıştır. Önemli bir alanda çalışma yürüten, öğrenmeyi kılavuzlayan öğreticilerin mahremiyet eğitimi konusundaki düşüncelerini anlamak, çalışmayı önemli kılmaktadır. Bu nedenle çalışmanın, 4-6 yaş Kur'an kursu öğreticileri başta olmak üzere, okul öncesinde görev yapan diğer öğretmen ve çalışanlara; ebeveynlere, spesifik anlamda mahremiyet eğitimi konusunu çalışan akademisyenlere, program geliştiricilere önemli katkılar sunacağı düşünülmektedir.

$\mathrm{Bu}$ çalışmada nitel araştırma modeli tercih edilmiştir. Çalışma için nitel araştırma desenlerinden biri olan durum çalışması/örnek olay deseni seçilmiştir. Durum çalışması, 'güncel bir olguyu kendi gerçek yaşam çerçevesi içinde çalışan ve durumları çok yönlü, sistemli ve derinlemesine inceleyen görgül bir araştırma yöntemi' olarak tanımlanmaktadır. Araştırmada örneklem, amaçlı örnekleme yöntemlerinden biri olan tipik durum örneklemesi yöntemi ile belirlenmiştir. Tipik durum örneklemesi “diğerleri gibi davranma olasıllğı yüksek olan bireylerin seçilmesi' anlamına gelmektedir. Bu araştırmada veri toplama aracı olarak görüşme/mülakat uygun görülmüştür. Görüşme, sosyal bilimler alanında yapılan araştırmalarda kullanılan en yaygın 
veri toplama yöntemlerinden birisidir. Binaenaleyh, görüşme bireylerin deneyimlerine, tutumlarına, görüşlerine, şikayetlerine, duygularına ve inançlarına ilişkin bilgi elde etmede oldukça etkili bir yöntemdir. 2019-2020 eğitim öğretim yılında Tokat il merkezinde öğretim faaliyeti yürüten 10 Kur'an Kursu öğreticisi ile mülakat yapılmıștır. Çalışma araçları vasıtasıyla elde edilen veriler analiz edilmiştir. Verilerin çözümlenmesinde içerik analizi yöntemi kullanılmıştır. İçerik analizi, "belirli kurallara dayalı kodlamalarla bir metnin bazı sözcüklerinin daha küçük içerik kategoriler ile özetlendiği sistematik, yinelenebilir bir teknik’ olarak tanımlanmaktadır.

Çalışmadan elde edilen bazı sonuçlar şu şekildedir; 4-6 yaş Kur'an kursu öğreticilerine göre mahremiyet kavramı başta insan kişiliği olmak üzere, ahlak, adap, din, toplum, eğitim, aile, okul ve bu kurumlardaki davranışların neredeyse tamamıyla ilişkilendirilebilen geniş bir içeriğe sahiptir. Kur'an kursu öğreticileri arasında mahremiyet eğitiminin tanımına ilişkin ortak bir anlayış görülmemiştir. 4-6 yaş Kur'an kursu öğreticileri cinsel eğitim ile mahremiyet eğitimi arasında bir ilişki olduğunu ancak mahremiyet eğitiminin daha geniş kapsamlı ve ihtiyaç karşılamaya daha uygun olduğunu düşünmektedirler. Öğreticiler mahremiyet eğitiminin doğrudan ahlak ve adap ile ilişkilendirilmesi gerektiğini düşünmüşlerdir. Bazı görüşlerde ise ahlak veya adap eğitimi yapmanın çocuğun mahremiyet algısı için yeterli olabileceği ileri sürülmüştür. Öğreticiler çoğunlukla mahremiyet eğitimini ahlak eğitimiyle bir şekilde ilişkilendirmişlerdir. Bu da mahremiyet eğitiminin geniş kapsamlı bir ahlak eğitimi olarak anlaşıldığını göstermektedir. Öğreticilere göre mahremiyet eğitimi, çocukların mutlaka alması gereken bir eğitimdir. Öğreticilerin bu konuda tam bir fikir birliği içerisinde oldukları görülmüştür. Öğreticilere göre bu eğitim, çocuğa kendisini ve başkalarını tanımak ve onlara saygı duymak gibi önemli katkılar sağlayabilir. Bu çalışmaya bağlı olarak şu önerilere yer verilmiştir; başta okul öncesi eğitim kurumları olmak üzere diğer tüm kurumlarda görev yapmakta olan öğretmen ve öğreticilere dönük, mahremiyet eğitimi temalı yeni, farklı alan çalışmaları yapılabilir. Bu çalışma hizmet öncesi eğitim programlarında mahremiyet eğitimine duyulan ihtiyacı göstermiştir. Bundan dolayı erken çocukluk eğitiminin her kademe ve kurumunda çalışan öğretmen ve öğreticilere planlı ve programlı bir mahremiyet eğitimi verilmesi, bu eğitimin öğretim programlarına dâhil edilmesi önerilebilir.

\section{Anahtar Kelimeler}

Din Eğitimi, Ahlak Eğitimi, Mahremiyet Eğitimi, 4-6 Yaş Kur’an Kursu, Kur'an Kursu Öğreticisi

\section{Giriş: Metodolojik Çerçeve}

Kur'an kursu önemli bir yaygın din eğitimi kurumudur. Bu kurumun temel amacı Kur'an ve temel dini bilgileri öğretmektir. Bu kurum varlık misyonuna uygun olarak çalışma alanını genişletti. ${ }^{1}$ Kur'an kursları, bir pilot uygulama olarak, 20132014 öğretim yılından itibaren okul öncesi çocuklarına da din eğitimi vermek amacıyla öğrenci kabul etmeye başladı. Bu kurslarda çeşitli eğitimler verilmektedir. Son dönemlerde artan çocuk istismarları gibi nedenlerle kurslarda mahremiyet eğitimine de yer verildiği görülmektedir.

\section{Problem}

Okul öncesi diğer tüm eğitim kurumları gibi okul öncesi dönemde hizmet vermeyi amaçlayan 4-6 yaş Kur'an kursları da çocuğun beden, zihin ve dini gelişimi ve din

1 Mehmet Korkmaz, “Kur’an Kurslarında Din Eğitimi ve Sorunları”, ed. Mustafa Köylü, Türkiye’de Din Eğitimi ve Sorunları (İstanbul: Dem Yayınları, 2018), 319-368. 
eğitimiyle de ilgilenmek durumundadırlar. Bu kurumlarda çocuğun temel ihtiyaçlarına uygun bir program ve metotlar uygulandığı sürece, bireyin her yönden gelişimi mümkündür. ${ }^{2}$ Okul öncesi dönemdeki çocukların yarının iyi, becerikli, mutlu insanı olmaları bağlamında söz konusu kurslarda bazı programlar uygulanmaktadır. Bunlar arasında mahremiyet eğitimi de vardır. Son dönemde artan çocuk istismarı vb. haberler başta olmak üzere başka faktörler göz önüne alınarak okul öncesi kurumlarda, ilgili programlarda yer verilmemesine rağmen, mahremiyet eğitimi konusunda çeşitli etkinliklere yer verildiği bilinmektedir. Amaç çocukların erken yaşlardan itibaren sağlıklı bir birey olarak yetişmeleridir. Çocukların olumlu nitelikler kazanmaları, bazı olumsuzluklara karşı duyarlı olmalarını amaçlayan bu uygulama ve bilgilendirmelerin önemli olduğu düşünülmektedir. Çocuk, evde öğrenmeye başladığı dil, din, ahlak, öz bakım becerileri, cinsiyet rolleri gibi özelliklerini, bunlarla ilgili öğrenmelerini okul veya Kur’an kurslarında geliştirmek durumundadır.

Çocukların sağlıklı bir birey olarak yetişmelerinde mahremiyet eğitiminin katkısının ne olduğu araştırmaya değerdir. Mahremiyet eğitimi çocuğun dini, ahlaki ve kültürel açıdan sağlıklı bir cinsel kimlik geliştirme eğitimidir, denilebilir. Bununla birlikte mahremiyet eğitimi çocuğun kendi özelini önemseme, koruma; başkasının özeline saygı duymayı içeren bir geniş kapsamlı bir eğitimdir. Bu eğitimin Kur'an kurslarında nasıl yer aldı̆̆ı, hangi etkinliklere yer verildiği önemli görülmektedir. Özellikle bu kurumlarda görev yapan, öğretmen, öğretici, yardımcı abla, sınıf annesi vb. sıfatlarla çalışan veya yer alan şahsiyetlerin mahremiyet ile ilgili tutum ve becerilerinin ne olduğunun anlaşılması önemli görülmelidir. Çünkü onlar çocuk ile önemli bir zaman dilimi geçirmekte ve ciddi etkileşim süreçleri yaşamaktadırlar.

Diyanet İşleri Başkanlığı'nın (DİB) 4-6 yaş Kur'an kursu projesi kapsamında ihdas edilen kurumların beraberinde bazı sorunlar getirdiği anlaşılmaktadır. Nitekim Kur'an kursu öğreticilerinin okul öncesi öğrencilerine dönük bazı tecrübeleri olmuştur. Bu minvalde DİB’in Milli Eğitim Bakanlığ1 (MEB) ile yaptığı protokol gereği okul öncesi eğitim kurumlarında Kur’an kursu öğreticileri görevlendirilmiştir. Öğrencilerin dini gelişimlerine katkıda bulunmak üzere görevlendirilen Kur'an kursu öğreticilerinin bu bağlamda aldıkları hizmet öncesi eğitimde bazı sorunların olduğu görülmektedir. ${ }^{3}$ Her eğitim kurum ve kademesinde sorunlar ortaya çıkabilir. Bundan dolayı sorunlar gerekçe gösterilerek çocukların din eğitimi ihtiyacı görmezlikten gelinmemelidir. Ancak okul öncesi çocukların din eğitimi ihtiyacını karşılamaya dönük proje çalışmalarının, uygulamalarının problemlerini tespit etmek, eksikliklerini gidermek, sorunlarını çözmek için bilimsel çabalar sarf etmek gerekiyor.

DİB’in 4-6 yaş Kur'an kursu projesi öğreticiler için de cesaret gerektiren çalışmalardır. Araştırma kapsamında olmayan bazı görüşmelerde bu kurumlardaki bazı öğreticiler çekinerek fakat sorumluluk yüklenerek bu işe gönüllü katıldıklarını; buna karşılık

2 Mustafa Tavukçuoğlu, “Okulöncesi Çocuğunun Eğitiminde Din Duygusu ve Din Eğitimi”, Selçuk Üniversitesi İlahiyat Fakültesi Dergisi 14 (2002), 61.

3 Tecelli Karasu, “Kur'an Kursu Öğreticilerine Göre Okul Öncesi Dönemde Din Eğitimi: Muş İli Örneği”, İlahiyat Tetkikleri Dergisi 1/51 (Haziran 2019), 483-484. 
bazı arkadaşlarının bu işten kaçındıklarını ifade etmişlerdir. Bu kaçınmada, öğreticilerin öğrenciyi tanıma, öğretimi ona göre planlama ve değerlendirme yeterliklerinin etkisi olduğu düşünülmektedir. Bazı öğreticilerin 4-6 yaş Kur’an kursu projesinden niçin kaçındıkları ayrıca bir çalışmanın konusu yapılabilir. Bununla birlikte 4-6 yaş Kur'an kursu öğreticilerinin yeterlik algılarını daha detaylı araştırmak gerekir. Bu tür araştırmaların ${ }^{4}$ alanı yakından tanımaya ve onu kontrol etmeye olumlu katkılar yapacağı söylenebilir. Çünkü çocukların öğrenme yaşantılarına ilişkin düzenli ve sürekli olarak veri toplanması, eğitim sürecine dâhil olan paydaş unsurların değerlendirilmesi, öğretime ilişkin doğru kararlar verilmesi için gereklidir. ${ }^{5}$ Aksi takdirde yüksek beklentilerle başlayan bu tür uygulamaların yeterince incelenmemesinin okul öncesi din eğitimi çalışmalarına zarar verebilme ihtimali de vardır. Bu nedenle, sürece dâhil olan tarafların konuyla ilgili değerlendirmeleri uzun vadeli planlamalar ve uygulamalar yapmaya ve daha sağlıklı sonuçlar almaya katkıda bulunabilir.6 $4-6$ yaş Kur'an kursu eğitimi, din eğitimcilerinin yakından takip etmesi gereken yeni bir uygulamadır. Bu nedenle söz konusu çalışmaların başarıya ulaşması, gerçekleștirilen uygulamalar hakkında bilgi edinmek ve bunları değerlendirmekle mümkündür. ${ }^{7}$

4-6 yaş Kur'an kursu projesi yeni bir uygulama sayılır. 2013-2014 eğitim öğretim yılında ilk kez uygulamaya konulan 4-6 yaş Kur'an kursu öğretim programında toplumdan gelen talepler doğrultusunda "değerler eğitimini” esas alan bir yaklaşım benimsendiği ifade edilmektedir. ${ }^{8}$ Konuyla ilgili ifade şöyledir; "söz konusu programla; çocukların kendi seviyelerinde sevgi, saygı, yardımlaşma, iyilik, adalet, sorumluluk, doğruluk ve sabır gibi İslam dininin temel değerlerini insan hayatına anlam kazandıran unsurlardan biri olarak fark etmeleri yanında dinimizin temel kaynağı olan Kur'an-1 Kerim'i ses ve şekil olarak kendi seviyelerinde tanımaları hedeflenmektedir. ${ }^{9}$ Ayrıca, 4-6 yaş Kur'an kursu Öğretim Programın tamamı incelendiğinde, ilgili programda açıkça bir mahremiyet eğitimi kavramının geçmediği görülmektedir. Ancak 4-6 yaş Kur’an kursu öğreticileri “değerler eğitimi” bağlamında mahremiyet eğitimi uygulamalarına yer vermektedirler. Bu durumun bir örneğinin diğer okul öncesi programlarında da yaşandığı ileri sürülmektedir. ${ }^{10}$

\footnotetext{
İlgili bazı çalışmalar için Bk. Muhammed Ali Yazıbaşı, “Kur'an Kursu Öğreticilerine Göre 4-6 Yaş Kur'an Kursu Öğreticisi, Öğrencisi ve Öğrenci Velisinin İhtivaç ve Beklentileri Kırıkkale Örneği”, Dini Arastırmalar 23/57 (Haziran 2020); Mehmet Korkmaz, 4-6 Yaş Kur'an Kurslarında Din Eğitimi (Sorunlar ve Çözüm Önerileri) (Kayseri: Kimlik Yayınları, 2019); Salih Aybey, “4-6 Yaş Grubu Kur’an Kurslarının Eğitim-Öğretim Faaliyetleri ve Problemleri (Zonguldak İli Örneği)”, Bülent Ecevit Üniversitesi İlahiyat Fakültesi Dergisi, 6/2 (Aralik 2019).

5 Tunçeli - Zembat, “Erken Cocukluk Döneminde Gelișimin Değerlendirilmesi ve Önemi”, 1.

6 Avsegül Gün, “Veli ve Öğretici Görüsleri Doğrultusunda 4-6 Yas Grubu Kur'an Kursu Eğitimi: Samsun İli Örneği”, Amasva Üniversitesi İlahivat Fakültesi Deraisi 7 (Aralık 2016), 61.

7 Gün, "Veli ve Öğretici Görüşleri Doğrultusunda 4-6 Yaş Grubu Kur'an Kursu Eğitimi: Samsun ìli Örneği", 37.

8 Kur'an Kursları Öğretim Programı (4-6 Yaş Grubu), (Ankara: DỉB Yayınları, 2018), 5.

9 Kur'an Kursları Öğretim Programı (4-6 Yaş Grubu), 6.

10 Kardeş - Güney Karaman, “Okul öncesi Öğretmenlerinin Çocuğun Cinsel Eğitimine İlişkin Görüşleri”, 1557.
} 
Bu çalışmada 4-6 yaş Kur'an kurslarında uygulanmakta olan ancak ilgili programda doğrudan ifade edilmeyen mahremiyet eğitimi araştırma konusu yapılmıştır. Böylece Kur'an kursu öğreticilerinin mahremiyet eğitimi konusundaki yeterliklerinin ortaya çıkarılması amaçlanmıştır. Öğreticilerinin mahremiyet eğitimi konusundaki bilgileri, uygulamaları, bu eğitimin önemi konusundaki düşünceleri önemli görülmektedir. Nitekim onların bu alandaki bilgi ve becerileri, çocukların gelişimine doğrudan etkide bulunmaktadır. Bununla birlikte nitelikli bir mahremiyet eğitimi ile çocuklara yönelik ihmal ve istismar olaylarının azalması da mümkün olabilir.

Mahremiyet eğitiminin önümüzdeki dönemlerde okul programlarında daha fazla yer alacağı düşünülmektedir. Özellikle okul öncesi dönemde bunun daha sıklıkla ele alınacağı ön görülmektedir. Ön görüden hareketle bu çalışmada, 4-6 yaş Kur'an kursu öğreticilerinin mahremiyet eğitimine ilişkin düşünceleri, yaklaşımları araştırılmak amaçlanmıştır. Buna göre çalışmanın temel problemi şudur: çocukların mahremiyet eğitimi ve bu eğitimin önemine ilişkin 4-6 yaş Kur’an kursu öğreticilerinin görüşleri nelerdir?

\section{Amaç ve Önem}

Mahremiyet eğitimine ilişkin öğretici görüşlerinin incelenmesi, öğretim programlarının geliştirilmesi açısından önemli görülmektedir. Mahremiyet eğitimi gibi önemli olduğu düşünülen bir konuda söz konusu eğitiminin uygulayıcıları tarafından ne anlama geldiği, nasıl algılandı̆̆ı, bu konudaki yeterlikleri gibi konuların araştırılması önemli görülmektedir. Bu araştırmada okul öncesi dönemin bir durum örneği olarak 4-6 yaş Kur'an kursu öğreticilerinin mahremiyet eğitimi hakkındaki bilgi ve tutumlarının neliğinin araştırılması amaçlanmaktadır. Çalışmanın, önemli bir alanda çalışma yürüten, öğrenmeyi kılavuzlayan öğreticilerin mahremiyet eğitimi konusundaki düşüncelerini anlamak, kendi meslektaşları başta olmak üzere, okul öncesinde görev yapan diğer öğretmen ve çalışanlara; ebeveynlere, spesifik anlamda mahremiyet eğitimi konusunu çalışan akademisyenlere, program geliştiricilere önemli katkılar sunacağı düşünülmektedir.

\section{Yöntem}

Bu çalışmada nitel araştırma modeli tercih edilmiştir.

\section{Araştırma Deseni}

Çalışma için nitel araştırma desenlerinden biri olan durum çalışması/örnek olay deseni seçilmiştir. Bir birey, bir kurum, bir grup çalışılacak durumlara örnek teşkil edebilir. Bu araştırma desenin en temel özelliği bir ya da birkaç durumun derinliğine araştırılmasına imkân tanımasıdır. Durum çalışması, 'güncel bir olguyu kendi gerçek yaşam çerçevesi içinde çalışan ve durumları çok yönlü, sistemli ve derinlemesine inceleyen görgül bir araştırma yöntemi’ olarak tanımlanmaktadır. ${ }^{11}$

11 Ali Yıldırım - Hasan Şimşek, Sosyal Bilimlerde Nitel Araştırma Yöntemleri (Ankara: Seçkin Yayıncılık, 2005), 277. 


\section{Çalışma Grubu}

Araştırmada örneklem, amaçlı örnekleme yöntemlerinden biri olan tipik durum örneklemesi yöntemi ile belirlenmiştir. Tipik durum örneklemesi “diğerleri gibi davranma olasılı̆̆ı yüksek olan bireylerin seçilmesi' anlamına gelmektedir. Patton'a göre tipik durum örneklemi yöntemi kilit katılımclların iş birliği ile seçilir. Tipik durumlar ayrıca "ortalama benzeri” vakaları tanımlamak için normal bir karakteristik dağılım sağlayan diğer istatistiksel veriler kullanılarak tercih edilebilir. ${ }^{12}$ Bu yöntem ile araştırmaya seçilen öğreticiler 4-6 yaş Kur'an kurslarında derslere giren öğreticilerden bir gruptur. Seçilen grubun, içinde bulunduğu büyük grubun benzer tutum ve davranışlarına sahip olduğu düşünülmektedir. 2019-2020 eğitim öğretim yılında Tokat il merkezinde öğretim faaliyeti yürüten 10 Kur'an Kursundan 1'er öğretici araştırmaya katılmıştır. Öğreticilerin tamamı kadındır. Kıdemleri 1-20 yıl arasında değişen öğreticiler, araştırmacı tarafından bilgilendirilmiş; mülakat formu kendilerine ulaştırılmış, iki tanesi ile telefonla görüşme yapılmıştır.

\section{Veri Toplama Arac1}

$\mathrm{Bu}$ araştırmada veri toplama aracı olarak görüşme/mülakat uygun görülmüştür. Görüşme, sosyal bilimler alanında yapılan araştırmalarda kullanılan en yaygın veri toplama yöntemlerinden birisidir. Çünkü görüşme bireylerin deneyimlerine, tutumlarına, görüşlerine, şikâyetlerine, duygularına ve inançlarına ilişkin bilgi elde etmede oldukça etkili bir yöntemdir. ${ }^{13}$

Görüşme yoluyla verilerin elde edildiği bu araștırmada, 4-6 yaş Kur'an kursu öğreticilerinin mesleklerini icra ederken, mahremiyet eğitimi bağlamında neler yaptıklarının tespit edilmesi amaçlanmıştır. Araştırmaya Tokat İli ve ilçelerinde çalışan yaklaşık 100 4-6 yaş Kur’an kursu öğreticisi arasından gönüllü 10 kişi ile çalışma yürütülmüştür. Öğreticilere araştırmacı tarafından mülakat formalarını doldurmak, yüz yüze veya telefonla görüşmek şeklinde farklı teklifler sunulmuştur. Söz konusu öğreticilerden 8'i mülakat formlarını doldurmayı; iki tanesi de telefon görüşmesi yapmayı kabul etmiştir. Yüz yüze görüşmeyi kabul eden öğretici olmamıştır. Telefon görüşmeleri ses kaydına alınmış ve araştırmacı tarafından yazıya aktarılmıştır.

Mülakat formlarının hazırlanması sürecinde araştırmacı tarafından açık uçlu sorulardan oluşan taslak bir görüşme formu hazırlandı. Din eğitimi biliminde iki alan uzmanına taslak formlar verildi. Onlardan gelen dönütler çerçevesinde formlar yeniden düzenlendi. Mahremiyet eğitimi mülakat formunun öğreticiler tarafından nasıl algılandığına dair bir ön uygulama yapıldı. Dört Kur'an kursu öğreticisine mülakat formu verildi. Bunlardan sadece üç tanesi bilgileri doldurup verdi. Üç öğreticinin soruların neredeyse tamamını cevapladıkları görüldü. Öğreticilerin formlara verdikleri cevaplara göre bazı sorular mülakattan çıkarıldı. Son şekli ile mülakat formu oluşturulup öğreticilere gönderildi.

12 Micheal Quinn Patton, Qualitative Research And Evaluation Methods (London: Sage Publication, 2002), 236.

13 Yıldırım - Şimşek, Sosyal Bilimlerde Nitel Araştırma Yöntemleri, 119. 


\section{Verilerin Analizi}

Çalışma araçları vasıtasıyla elde edilen veriler analiz edilmiştir. Verilerin çözümlenmesinde içerik analizi yöntemi kullanılmıştır. İçerik analizi, ‘belirli kurallara dayalı kodlamalarla bir metnin bazı sözcüklerinin daha küçük içerik kategoriler ile özetlendiği sistematik, yinelenebilir bir teknik' olarak tanımlanmaktadır. ${ }^{14}$ Yazılı doküman halinde elde edilen veriler üzerinde (1) veriler kodlanmış, (2) temalar bulunmuş, (3) kodlar ve temalar düzenlenmiş ve (4) bulgular tanımlanmış ve yorumlanmıştir. $^{15}$

Çalışmada çeşitli kodlamalar ve kısaltmalar kullanılmıştır. "4-6 yaş Kur’an kursu öğreticileri” kavramı bazen "öğreticiler”; “4-6 yaş Kur’an kursu” yerine de bazen sadece "Kur'an kursu” kavramı kullanılmıştır. Analiz ve değerlendirmelerin anlaşılır olması için öğreticilerin görüşlerinden doğrudan alıntılar yapılmıştır. Bunlar tırnak içerisinde gösterilmiştir. Bu görüşlerin sonunda ilgili öğreticinin görüşünü yansitması için, Kur'an kursu öğreticisi, örneğin Kur'an kursu öğreticisi 1 (KKÖ 1), Kur’an kursu öğreticisi 2 (KKÖ 2)... şeklinde kodlarla belirtilmiştir.

\section{Bulgular ve Yorumlar}

Araştırmaya katılan tüm bireyler kadındır. Araştırmaya katılan öğreticilerin 9'u evli biri ise bekârdır. Bekâr öğretici dışında kalanların hepsi 35 yaş ve üstüdür. Öğretmenlik, hayat, çocuk tecrübesi bakımından deneyimli, kendini rahat ifade edebilecek potansiyele sahip bireylerden oluştuğu söylenebilir. Katılımcı grubun önünde çalışmak için bir zaman; geriye dönük ise zengin sayılabilecek deneyimlerinin olduğu ileri sürülebilir.

Araştırmaya katılan öğreticilerin sadece 3 tanesi lisans mezunu olduğunu ifade etmiştir. Diğerlerinin tamamı ön lisans mezunudur. Özdemir ve Kavak'ın Kur'an kursu öğreticileri ile ilgili yaptığı bir çalışmada bunların ağırlıklı olarak İlahiyat lisans mezunu olduklarını, bununla birlikte İlahiyat ön lisans mezunlarının da önemli bir orana sahip olduğunu ortaya çıkarmıştır. Çalışmayı yürütenler bunu Kur'an kursu öğreticilerinin öğrenim düzeylerinin yüksek olduğu ${ }^{16}$ şeklinde değerlendirmişlerdir. Samsun'da yapılan bir araştırma da ise öğrenim düzeyleri arasında daha farklı bir durum ortaya çıkmıştır. ${ }^{17}$ Korkmaz'ın yaptığı geniş çaplı araştırmada, 4-6 yaş Kur'an kurslarında, ön lisans mezunları ile imam hatip lisesi mezunları toplamının yaklaşık \%55 civarında ve katılımcıların büyük çoğunluğunu oluşturduğu ${ }^{18}$ ortaya çıkmıştır. Bu çalışmalardaki veriler arasında önemli bir farklılık vardır. Tokat örneğindeki çalışmamızda da lisans mezunu öğretici sayısı ön lisans mezunu sayısından daha az

14 Șener Büyüköztürk, vd. Bilimsel Araștırma Yöntemleri (Ankara: Pegema Yayıncılık, 2008), 253.

15 Yıldırım - Simșek, Sosval Bilimlerde Nitel Arastırma Yöntemleri, 228.

16 Şuayip Özdemir - Rahime Kavak. “Öğretici Görüşlerine Göre Yaz Kur'an Kursları (Elâzığ Örneği)”, Uluslararası Sosval Arastırmalar Deraisi 4/18 (2011), 312.

17 Gün, "Veli ve Öğretici Görüşleri Doğrultusunda 4-6 Yaş Grubu Kur'an Kursu Eğitimi: Samsun İli Örneği”, 39.

18 Korkmaz, 4-6 Yaş Kur'an Kurslarında Din Eğitimi, 28. 
görünmektedir. Çalışma grubunda lisansüstü mezun öğretici ise hiç bulunmamaktadir.

Öğreticilerin çoğunun ön lisans mezunu olması pedagojik formasyon yeterliği açısından sorunlu görülmektedir. Lisans döneminde alınan pedagojik eğitimin niteliği ile ilgili tartışmalar bir yana bu eğitimden tümüyle mahrum olmak çok önemli bir eksiklik olarak düşünülmektedir. 4-6 yaş Kur’an kursu ile ilgili bir araştırma sonucu, öğreticiler arasında mesleki ve pedagojik formasyon açısından kendilerini tam yeterli görenlerin sayısının \%50'nin altında olduğunu; üçte birinin kısmen yeterli gördüğünü ve dörtte birinin ise yeterli görmediğini ortaya koymaktadır. Kendisini yeterli görmeyenlerin çoğunluğu İmam Hatip Lisesi mezunlarından oluşmaktadır. ${ }^{19}$ Korkmaz, okul öncesi dahi olsa, imam hatip lisesi veya ön lisans mezunu öğreticilerin, çocukların eğitimindeki yeterliklerinin tartışılması gereken bir konu olduğunu ileri sürmektedir. ${ }^{20}$ Yanlış anlaşılmalara mahal vermemek, okul öncesi din eğitimi ve din eğitimcisinin önemini de belirtmek için, Korkmaz’ın "okul öncesi dahi olsa...," ifadesini "okul öncesi de dahil..." ile değiştirmek daha isabetli olur. Koç da Kur’an kursu öğretici niteliklerinin geliştirilmesi gerektiğini; öğreticilerin hizmet öncesi eğitimlerinin yetersiz olduğunu, bu kurumlarda yüksek öğrenim görmüş olan öğretici sayılarının az buna bağlı olarak pedagojik formasyon alan öğretici sayısının da çok az olduğunu ifade etmiştir. ${ }^{21}$ Korkmaz'ın çalışmasında da Kur'an kursu öğreticileri arasında pedagojik formasyonu olan görevlilerin oranın düşük olduğu tespit edilmiştir. ${ }^{22}$

4-6 yaş Kur'an kursu öğreticilerine "mahremiyet ile ilgili bir eğitim aldınız mı?" şeklindeki soruya 4 öğretici evet, 3’ü hayır, kalan üçü de seminerlerde aldıkları bilgileri işaret etmişlerdir. Buna bağlı olarak öğreticilere kendilerini mahremiyet eğitimi konusunda yeterli bulup bulmadıkları sorulmuş, bununla ilgili olarak sadece iki kişi kendisini bu konuda yeterli gördüğg̈nü ifade etmiştir. 3 öğretici kendisini kısmen yeterli bulduğunu, buna karşılık 3 öğretici de kendisini yeterli bulmadığını belirtmişlerdir. Bir öğretici ilgili soruyu boș bırakmıștır. Kendisini kısmen yeterli gören bir öğretici "daha ayrıntılı bilgi almak isterim” (KKÖ 6) şeklinde geliştirilmesi gereken bir yönü olduğunu belirtmiştir. Kendisini yeterli bulan öğreticilerden birisinin ifadesi şöyledir; “41 yaşındayım. Beş çocuk yetiştirmiş bir anne olarak zorlandığımı düşünmüyorum. Rahat olduğumu düşünüyorum. Profesyonel olduğumu düşünüyorum artık" (KKÖ 10). Bazı öğreticilerin işaret ettiği kişisel tecrübelerin öğretmenlik yaşamındaki önemi yadsınamaz. Ancak bunun yeterli olduğunu düşünmek sorunlu görülebilir. Aybey de öğreticilerin kendilerini pedagojik formasyon konusunda yeterli

19 Aybey, “4-6 Yaş Grubu Kur’an Kurslarının Eğitim-Öğretim Faaliyetleri ve Problemleri (Zonguldak İli Örneği)”, 236.

20 Korkmaz, 4-6 Yas Kur'ân Kurslarında Din Eăitimi, 29.

21 Ahmet Koç, “Kur'an Kurslarında Eğitim ve Verimlilik Üzerine Bir Araştırma (Tespitler-Öneriler)”, Etkili Din Öğretimi (İstanbul: TiDEF Yayınları, 2010), 512-513.

22 Mehmet Korkmaz, Kur’an Kursu Öğreticilerinin Eğitim-Öğretim Yeterlikleri, DỉB Yayınları, Ankara, 2012, 97; Mehmet Korkmaz, “Öğretici Görüşlerine Göre Yaz Kur'an Kurslarının Sorunları (Kayseri Örneği)”, Bilimname 21/2 (2011), 136. 
görmelerinin yetmeyeceğini, daha iyi bir öğretici olmak için hizmet içi eğitimlere devam edilmesi gerektiğini de ayrıca vurgulamaktadır. ${ }^{23}$ Korkmaz, Diyanet İşleri Başkanlığının 4-6 yaş Kur'an kurslarında görev yapan öğreticilerin eğitimine yönelik olarak hizmet içi eğitim seminerleri düzenlemekte olduğunu ancak hali hazırda oldukça önemli sayılabilecek bir öğretici grubunun bu seminerlere katılmadığını ifade ettiklerini ${ }^{24}$ belirtmektedir. Benzer bir bilimsel çalışmaya göre öğretmenler, çocukların cinsel eğitimlerine yönelik seminerler, konferanslar, hizmet içi eğitimler ve lisans düzeyinde dersler verilmesinin uygun olacağını ifade etmişlerdir. ${ }^{25}$

Görüldüğü gibi mahremiyet eğitimi konusunda 4-6 yaş Kur'an kursu öğreticileri kendilerini kısmen yeterli görmektedirler. Ancak eksikliklerinin olduklarını da düşünmektedirler. Öğreticilerin mahremiyet eğitimindeki yeterliklerine ilişkin görüşlerinde genellikle ihtiyatlı yaklaştıkları öne çıkmaktadır. Bu durum, mahremiyet gibi spesifik bir alandaki yeterlikle ilişkilendirilebilir. Daha geniş kapsamda okul öncesi dönemde öğretmenlik yapmanın güçlüğüne matuf olduğu da düşünülmektedir. Nitekim yapılan bir araştırmada 4-6 yaş Kur'an kursu öğreticilerinin bu dönem için yeterli donanımda olmadıkları ifade edilmiştir. ${ }^{26}$

4-6 yaş Kur'an kursu öğreticiliği son derece iyi bir donanım ${ }^{27}$ ve tecrübe gerektiren bir çalışma alanıdır. Bu kurslarda gerçekleştirilen din eğitiminin etkililiği de bu programları uygulayan öğreticilerin niteliğiyle/yeterliğiyle doğrudan ilişkilidir. $^{28}$

Çalışmanın bu kısmında, 4-6 yaş Kur'an kursu öğreticilerinin doğrudan mahremiyet eğitimi ve onun kapsamı, önemi ve ilişkili olduğu diğer unsurlarla ilgili düşünceleri ilgili literatür çerçevesinde analiz edilmiştir.

\section{1. Öğreticilere Göre Mahremiyet ve Mahremiyet Eğitimi}

4-6 yaş Kur'an kursu öğreticileri "Mahremiyet sizce nedir? Hangi konular mahremiyet içerisinde yer alır?" şeklinde sorular sorulmuştur. Onlar, bu soruya çeşitli şekillerde cevap vermişlerdir. Bununla ilgili öğreticilerin görüşlerine bakıld1ğında bu kavramın genel olarak bireye münhasır, insanın özeline ait bir kavram olduğu vurgulanmıştır. Kavramın ve oluşturduğu içeriğin insan için ne derece önemli olduğu ifadelerden anlaşılmaktadır. Mahremiyet kavramı tüm insani ilişkilerle ilişkilendirilebilen ve korunması gereken bir değer olduğu da belirtilmiştir. Bunu ifade eden görüşlerden biri şöyledir;

23 Aybey, “4-6 Yaş Grubu Kur’an Kurslarının Eğitim-Öğretim Faaliyetleri ve Problemleri (Zonguldak İli Örneği)", 236.

24 Korkmaz, 4-6 Yaş Kurân Kurslarında Din Eğitimi, 35.

25 Kardeş - Güney Karaman, “Okul Öncesi Öğretmenlerinin Çocuğun Cinsel eğitimine İlişkin Görüşleri”, 1563.

26 Gün, "Veli ve Öğretici Görüşleri Doğrultusunda 4-6 Yaş Grubu Kur'an Kursu Eğitimi: Samsun İli Örneği”, 40.

27 Ayrıntılı bilgi için bk. Muhammet Şevki Aydın, Bir Din Eğitimi Kurumu Olarak Kur’an Kursu (Ankara: DİB Yayınlar1, 2008).

28 Aydın, Bir Din Eğitimi Kurumu Olarak Kur'an Kursu, 117. 
"Mahremiyet kişinin kendi özel alanıdır başkasına yasak olan kişisel mahremiyetidir. Kişinin haram sayılan bölgeleriyle birlikte yaşamının özel durumları da mahremiyet kavramı içerisindedir. Eşlerarası ilişkiler, aile içi münasebetler, komşuluk ilişkileri de mahremiyet kavramı içerisindedir. Bu ilişkilerden başkalarının yanında ifşa edilmemelidir" (KKÖ 4).

Bazı öğreticiler mahremiyetin sadece cinselliği içermeyen, cinselliği, cinsel yaşamı da kapsayan daha geniş bir anlam ifade ettiğini de belirtmişlerdir; "Bir insanın özeli, kişiliğini oluşturan her şeyin eğitimi, duyguların yönetilmesini öğretmek, sadece cinsel konular değil, öfke, utanma, kıskançlık gibi insani duygular" (KKÖ 6).

Bir öğretici özellikle mahremiyet alanı ile din ilişkisini kurmuştur; "Her şeyde mahremiyet var ama dinle ilgisi daha fazla olduğunu düşünüyorum. Sağllk kurumunda doktor hasta arasında da mahremiyet var; olması gerektiği kadarıyla her türlü ilişkide mahremiyet var" (KKÖ 9).

Mahremiyetin kapsamına dair öğretici görüşleri incelendiğinde, onların bu kavramın kapsamını oldukça geniş tuttukları anlaşılmaktadır. 4-6 yaş Kur'an kursu öğreticileri bu kavramın cinsellikle birlikte anılmakla beraber, içerisinde sevgi, saygı, duyguların kontrolü gibi özelliklerin yattığını anlamaktadıllar. Özaslan ve Gültekin Akduman tarafından yapılan bir araştırmada da mahremiyetin katılımcılar tarafından geniş kapsamlı ifade edildiğgi ${ }^{29}$ görülmektedir. Görüldüğü üzere 4-6 yaş Kur'an kursu öğreticilerinin mahremiyet kavramının tamamına ve kapsamına ilişkin görüşleri, bu kavramı anlamlandırmaları diğer araştırmalarda ortaya çıkan veriler ile benzerlik göstermekedir. Dolayısıyla Kur’an kursu öğretici görüşleri ile diğer araştırmalarda ortaya çıkan bazı görüşleri örtüşmektedir. Ayrıca öğretici görüşlerinde mahremiyet kavramının doğrudan din ile ilişkilendirilmesi son derece önemli görülmektedir. Yaygın din eğitimi kurumlarında din eğiticisi olarak çalışan bir bireyin mahremiyet ile din arasında bir ilişki kurması doğal karşılanabilir. Ancak mahremiyet değerinin belirlenmesinde din faktörünün ifade edilmesi, bu doğal ilişkinin ötesinde bir anlama sahip olduğu söylenebilir. Mahremiyetin din ile ilişkilendirilmesi, mahremiyet sınırlarının ve ilkelerinin belirlenmesinde dinin en önemli, en temel kurum olma özelliğini ortaya çıkarmaktadır. Çünkü bir davranışın neden yasaklandığı, sınırlandırıldığı, çerçevesinin belirlendiği vs. noktasında din insanlara çok önemli etkilerde bulunmaktadır. Mahremiyet konusu işlenirken -özellikle dindar bir topluluk açısındanonu dinden bağımsız düşünmek olanaksız görünmektedir. Zaten mahremiyetin kelime ve istılahî anlamlarına bakıldığında haram kavramının bir türevi olduğu ve çerçevesinin öncelikle din tarafından belirlendiği anlaşılmaktadır. ${ }^{30}$

29 Bk. Hatice Özaslan - Gülümser Gültekin Akduman, “Ailelerin Mahremiyet Eğitimine İlişkin Görüşlerinin İncelenmesi." ISAS2018-Winter - 2nd International Symposium on Innovative Approaches in Scientific Studies, Samsun, Turkey, November 30-December 2 2018, ed. Turgut Özseven - Volkan Karaca (Samsun: SETSCI Conferans Indexing System, 2018), 3/1363-1369.

30 Ahmed b. Muhammed el-Feyyûmî, el-Miṣbâhu'l-münîr, (Beyrut: Dârü'l-Kütübi'l-İlmiyye, ts.), 1/131. 
Mahremiyet mahrem kavramından türemiş bir mastardır. Bu kavram da haram kökünden gelir ve gizlilik, ${ }^{31}$ bir şeyin gizli hali, bir şeyin gizli yönü ${ }^{32}$ anlamalarını içerir. İnsan ilişkileri açısından buna insanın özel dokunulmazlık alanı da denebilir. Mahrem ve mahremiyet kavramlarının özellikle cinsel dokunulmazlık alanı anlamına geldiği anlaşılmaktadır. Bir insanın dokunulmazlık alanına bakmak, dokunmak ve hakkında konuşmak mahremiyetin kapsamında yer almaktadır ve bu alan diğer kişiler için yasaklanmış alan olarak ifade edilebilir.

Mahremiyet kavramının kapsamının belirlenmesinde kültür faktörü önemlidir. Her kültürde bu alanın genişliği farklılaşmakla birlikte varlığını sürdürmektedir. Haliyle bu kavramın içeriğinin belirlenmesinde dinin önemli bir belirleyici, hatta en belirleyici unsur olduğu ileri sürülebilir. ${ }^{33}$

Açıklamalardan hareketle, mahremiyet-din ilişkisinin çok yönlü çalışılmasına ihtiyaç vardır, denilebilir. Bu bağlamda, "mahremiyet eğitiminin dinle bir ilişkisi var mı? Dindar olmayanlar bu eğitimi alabilir mi? şeklindeki bir soruya bir öğretici şöyle bir cevap vermiştir; "onlar için de gerekli bir şey diye düşünüyorum. İnsanın olduğu her yerde bu eğitim gereklidir” (KKÖ 9). Bu açıklamaya göre 4-6 yaş Kur'an kursu öğreticileri mahremiyet eğitiminin dindarlık için gerekli olduğunu düşünmektedir. Bununla birlikte öğreticiler, bu eğitimin dindarlık dışındaki diğer insani ilişkiler için de gerekli olduğunu düşünmektedirler. Mahremiyetin hem insanın dindarlığını inşa etmesinde hem de insanlarla ilişkilerinde önemli bir rolü vardır. Çünkü mahremiyetin merkezinde saygı vardır; özele saygı. Özele sahip olmak da saygı duymak da insana özgü niteliklerdir. Dolayısıyla böyle bir eğitim her bireye katkıda bulunur, denilebilir.

4-6 yaş Kur’an kursu öğreticilerinin "Mahremiyet eğitimi sizce nedir?” sorusuna verdikleri cevaplar incelendiğinde, aralarında tam bir fikir birliği olmadığı görülmüştür. Bazı açıklamalarda ise oldukça genel ifadelerin kullanıldığı görülmektedir. Örneğin; "Mahremiyet kişinin kendisini, çevresini tanıması, hakkında gerekli bilgileri bilmesidir" (KKÖ 2). Bazı ifadelerde ise mahremiyet eğitimi tanımından ziyade bu eğitimin amaçları ön plana çıkarılmıştır. Örneğin; "Bebeklikten itibaren alması gereken kişiyi koruma amaçlı eğitim” (KKÖ 1) veya "mahremiyet eğitimi çocuğun mutlaka alması gereken bir olay olarak. Mahremiyet eğitimi insanın kendi cinsine karşı kendini koruması" (KKÖ 9). "Mahremiyet insanın kendini dışa dönük olarak her türlü tehlikeden koruması yani bu şekilde” (KKÖ 9).

4-6 yaş Kur'an kursu öğreticileri, mahremiyet kavramına kapsayıcı anlamlar yüklemelerine rağmen geniş kapsamlı bir mahremiyet eğitimi tanımı yapamadıkları görülmüştür. Ayrıca öğreticiler arasında tam bir tanım birliğinin olmadığı da anlaşılmaktadır. Öğreticilerin mahremiyet eğitimini tanımlayamamalarının veya tanım birliği içerisinde olmamalarının bazı olumsuzlukları olabilir. En başta bir şeyi tanımlayamamak o

31 TDK Güncel Türkçe Sözlük, "Mahremiyet” (Erişim 17 Mayıs 2020)

32 Mazhar Bağlı, Modern Bilinç ve Mahremiyet (İstanbul: Yarın Yayınlar, 2011), 184-185.

33 Bağll, Modern Bilinç ve Mahremiyet, 185. 
şeyin mahiyeti hakkında yeterli bilgiye sahip olunmadığına işarettir, denilebilir. Mahiyeti tam olarak bilinmeyen bir şeyin içeriğini oluşturmak, öğrenme sürecini takip etmek oldukça güçleşir. Öğreticiler arasında bir tanım birliğinin olmaması öğrenme ürünleri açısından tesadüfi öğrenmelere yol açabilir ki öğrenme, öğretmenin kendi bireysel, günlük performansına göre şekillenir. Bu da öğrenmede ortak hedeflerin gerçekleşmesini, öğrencilerin istendik davranışlar kazanmasına engel olur, denilebilir.

4-6 yaş Kur'an kursu öğreticilerinin ortak tanım yapamamalarının birçok nedeni ileri sürülebilir. Evvela mahremiyet kavramı ve haliyle mahremiyet eğitimi çok değişkenli, çok boyutlu kavramlardır. İkincisi, ilahiyat ve ahlak alanında mahremiyet konusunun yeterince işlenmediği söylenebilir. Üçüncüsü mahremiyet eğitimi için geleneksel eğitim anlayışının yeterli görülmesi olabilir. Çünkü geleneksel eğitim anlayışında ahlak ve adaba ilişkin birçok davranış gözlem yoluyla tevarüs edilebiliyordu. Ya da bazı telkinler yeterli görülebiliyordu. Ancak günümüz toplumlarında çocukların etkileşimde bulundukları unsurlar düşünüldüğünde mahremiyete ilişkin kazanımları geleneksel yollarla; doğrudan gözleyerek, özdeşim yaparak elde etmeleri güçleşmiştir. Ebeveynlerin çalışma hayatları, çocuklarına yeterli zaman ayıramaması, internet, bilgisayar, tv gibi benzeri teknolojilerin çocukları daha çok etkilemesi geleneksel yollarla öğrenmeyi neredeyse olanaksız hale getirmiştir. Bundan dolayı özel olarak hazırlanmış, düzenlenmiş ortamlara ihtiyaç vardır. ${ }^{34}$ Dinin, ahlakın, eğitimin dolayısıyla din eğitiminin mahremiyet eğitimi ile ilgilenmesi gerekir. $\mathrm{O}$ zaman mahremiyetin kapsamı ve tanımı konusunda ortak düşünceler oluşabilir.

Mahremiyet eğitimi ile ilgili çalışmaların artmaya başladığı görülmektedir. Ancak alan yazında artan çalışmalara rağmen mahremiyet eğitimi tanımı üzerinde fazla durulmadığı; yapılan tanımların ise oldukça soyut olduğu düşünülmektedir. ${ }^{35} \mathrm{Bu}$ tanımlara arasında şunlara rastlanmaktadır; duyguların yönetimi eğitimi, davranışların yönetimi eğitimi, beden dilinde estetik kazanımı eğitimi, nezaket ve zarafet eğitimi, ilişkilerde saygınlık eğitimi, cinsel bilgi kazanımı eğitimi. ${ }^{36}$ Bu tanımların her birisinin mahremiyet eğitiminin bir yönünü öne çıkardığı, ancak tamamını kapsayan bir tanım yapma ihtiyacının hala devam ettiği söylenebilir. Mahremiyet eğitimi ile ilgili kapsayıcı ve somut nitelikler ihtiva ettiği düşünülen tanım şudur; "mahremiyet eğitimi, çocuklara ve ergenlere kendi ve karşı cinsin özellikleri hakkında bilgi sahibi olma, cinsiyete ilişkin rolleri anlama ve kabul etme, cinsel problemlerini/ihtiyaçlarını dinin, ahlakın ve kültürün belirlediği çerçevede cevaplamanın/gidermenin yollarını öğretmek amacıyla verilen eğitimdir". ${ }^{37}$ Tanımdan hareketle mahremiyet eğitiminin cinsel eğitimi de içeren geniş bir kapsama sahip olduğu söylenebilir. Mahremiyet eğitimi tanımlarına insan

34 Süleyman Akyürek, Din Öăretimi (Ankara: Nobel Yavınları, 2010), 57.

35 Avrıntılı bilgi için bk. Adem Güneș, "Cinsel istismar olgusu ve mahremivet eğitimi," İnsan ve Toplum 7/2 (2017); Yusuf Bahri Gündoğdu, "Mahremivet Eğitiminin Temeli İnsanlık Serefi: Ailenin Mesulivetleri," ODÜ Sosval Bilimler Arastırmaları Deraisi (ODÜSOBİAD) 7/2 (2017); Saadet İder, "Yetişkinlerde Mahremivet Algısının Kavnağına İlișin Nitel Bir Arastırma," Marife 19/1 (2019).

36 Adem Günes, Nezaket ve Zarafet İcin Mahremivet Eăitimi (İstanbul: Timas Yavınları, 2015), 18-19.

37 Ramazan Diler, "Mahremiyet Eğitimi ve Önemi", Gaziosmanpaşa Üniversitesi İlahiyat Fakültesi Dergisi 2/1 (2014), 79. 
onuru, öz saygı, insan şahsiyeti, kişilik hakları gibi boyutları da içerecek yeni bir tanımın oluşturulabileceği de ifade edilebilir. Buna göre çocukların insan onuru, öz saygı, insan şahsiyeti gibi değerleri benimsemeleri, cinsiyet rollerini dinin, ahlakın, kültürün normları ile birlikte öğrenmeleri, istendik bir kişilik geliştirmeleri, bunu toplumsal ilişkilere yansıtmaları mahremiyet eğitiminin amacı ve önemine dair ipuçlarını yansıtmaktadır.

\section{2. Öğreticilere Göre Mahremiyet Eğitimi ile Cinsel Eğitim İlişkisi}

4-6 Yaş Kur'an kursu öğreticileri, “"Mahremiyet eğitimi ile cinsel eğitim aynı anlama gelir.' Görüşüne katılır mısınız?” şeklindeki soruya farklı cevaplar vermişlerdir. Bazı ÖÖKK öğreticilerine göre cinsel eğitim ile mahremiyet eğitimi aynı şey değildir. Bu düşüncede olan öğretici görüşlerine göre cinsel eğitim mahremiyet eğitimine göre daha sınırlıdır, insanla ilgili bazı durumları kapsamamaktadır. Örneğin; “Hayır, çünkü insanların özeli sadece cinsellik değildir" (KKÖ 8).

Bazı öğretici görüşlerine göre, uyarıcı, hatırlatıcı, olumsuz bir farkındalık yarattığı için çocuklara cinsel eğitim vermek gerekmez. Bundan dolayı da mahremiyet eğitimi ile cinsel eğitimin aynı anlama geldiğine katılmadığını belirtmiştir. Görüşüşü şöyledir; "Katılmıyorum hocam. Maalesef bu tür şeyler bilinçlendirmek adına iyi ama hatta çocuklarımızın daha çok ilgisini çekmeye başlıyor. Bizden önceki nesiller cinselliği öğrenerek mi bir yere geldiler" (KKÖ 9).

4-6 yaş Kur'an kursu öğreticilerinin cinsel eğitim ve mahremiyet eğitimi ilişkisi incelendiğinde öğreticilerin cinsellik ve cinsel eğitim hakkında olumsuz bir yargıya sahip oldukları anlaşılmaktadır. Örneğin;

"Hani hemşireler gelip bir şeyleri açık seçik konuşurlar ya. Bu şekilde basite indirgemiş bir paket program olarak sunulması şeklinde verilmesi doğru değil. Bunu dini hassasiyetleri olan insanların anlatması daha doğru olur. Diğer anasınıfı öğretmenlerinin de kendi çocukları gibi yetiştirdiklerini bu konuda hassas olduklarını düşünüyorum. Bir de bunun ilahi bir kural, kanun olduğunu düşünüyorum, dinle ilişkilendirilmesi gerektiğini düşünüyorum" (KKÖ 10).

Bazı öğreticiler ise cinsel eğitimin ancak mahremiyet eğitiminin bir parçası olabileceğini savunuyorlar; “... Çünkü cinsel eğitim mahremiyet eğitimi içerisinde yer alır. Ama sadece cinsel eğitim mahremiyet eğitimi için yeterli değildir” (KKÖ 2).

Öğretici görüşlerine göre mahremiyet eğitimi cinsel eğitime tercih edilmelidir. Onlar mahremiyet eğitiminin kapsayıcı buna karşılık cinsel eğitimin bazı değerleri görmezden gelici tarafı olduğunu düşünmektedirler. Hatta bazı öğreticiler cinsel eğitimin cinsellikle ilgili bazı halleri tetikleyebileceğini ileri sürerek bu eğitimin yarardan çok zarar getirebileceğini ifade etmişlerdir.

Dünyada cinsel eğitim kavramı cinsellik kavramından doğrudan etkilenmektedir. Dünya Sağlık Örgütü (DSÖ) cinselliğin zaman içeresinde anlam genişlemesine uğradığını açıklar ve cinselliği en geniş haliyle şöyle ifade eder;

"Cinsellik yaşam boyunca insan olmanın merkezi bir yönüdür; cinsiyet, cinsiyet kimlikleri ve rolleri, cinsel yönelim, erotizm, zevk, samimiyet ve üremeyi kapsar. Cinsellik düşünceler, fanteziler, arzular, inançlar, tutumlar, değerler, davranışlar, uygulamalar, roller ve ilişkilerde yaşanır ve ifade edilir. Cinsellik bu boyutların tümünü 
içerebilirken, hepsi her zaman deneyimlenmez veya ifade edilmez. Cinsellik biyolojik, psikolojik, sosyal, ekonomik, politik, kültürel, yasal, tarihsel, dini ve manevi faktörlerin etkileşiminden etkilenir." ${ }^{38}$

Bu açıklama incelendiğinde cinselliğin kültürel, dini ve manevi etkileşimi doğrudan ifade edilmiştir. Bu bağlamda cinsellik ile dini değerler ilişkisinin kurulduğu cinsel eğitimin de buna göre şekillenmesi; cinsel eğitimde, cinsel davranış ve ilişkilere ilişkin dini bakış açısının tam ve doğru bir şekilde sunulmasi ${ }^{39}$ gerektiği belirtilmektedir.

DSÖ’nün cinselliği tanımlaması, cinsel eğitimin yeniden tanımlanmasının ve içeriğinin genişlemesinin bir sonucu olarak bunun doğrudan mahremiyet anlayışını ve eğitimini ilgilendirdiği iddia edilebilir. Çünkü cinselliğin hangi dinde, hangi ahlak anlayışında ve kültürde nasıl tecessüm ettiği mahremiyetin; dolayısıyla mahremiyet eğitiminin kapsamında değerlendirilmelidir.

Cinsel eğitimi de içine alan mahremiyet eğitiminin genel amacı, kişinin hayatını hem kendi sınırlarını gözeterek hem de başkalarının sınırlarına riayet ederek yaşanmasına zemin oluşturmaktır. ${ }^{40}$ Cinsel eğitimin eksik bıraktıklarını tamamlamak ve bu eğitim üzerine inşa edilmek üzere bir mahremiyet eğitimi tasavvuru geliştirilebilir. Mahremiyet eğitimi ayrıca çocuğun sağlıklı bir cinsel kimlik gelişimine katkı sağlar. Çocuk bu eğitim sonucunda kendi özel alanlarını ve başkalarının özel alanlarını bilir ve korumasını öğrenir. Çocuk hem kendi özel alanlarına karşı başkalarından saygı beklemeleri hem de başkalarının özel alanlarına saygı göstermeleri gerektiğini öğrenmiş olabilir. ${ }^{41}$

Öğretici görüşlerinden hareketle cinsel eğitimin önemli olmakla beraber bu eğitimin tek başına yetmeyeceği; çünkü bu eğitimin yalnız başına çocuklar ve gençler üzerinde bazı uyarıcı etkilerinin olabileceği anlaşılmaktadır. Bundan dolayı cinsel eğitimi de içine alan ve din ve ahlak bakış açısını sunan mahremiyet eğitiminin daha kapsayıcı ve önemli olduğu görülmektedir.

\section{3. Öğreticilere Göre Mahremiyet Ĕgitimi ile Ahlak/Adap Eğitimi İlişkisi}

“'Mahremiyet eğitimi ile ahlak/adap eğitimi aynı anlama gelir." Görüşüne katılır mısınız?" boyutunda 4-6 yaş Kur'an kursu öğreticilerinin büyük çoğunluğu mahremiyet eğitimi ile ahlak veya adap ile organik bir bağ olduğunu göstermişlerdir. Hatta ortaya çıkan bazı düşüncelere göre ahlak veya adap merkezli bir eğitim yapmak mahremiyet eğitimine olan ihtiyacı ortadan kaldırabilir. Bu görüşşöyle ifade edilmiştir;

38 World Health Organization (WHO), "Sexual health, human rights and the law”, (Erişim 19 Mayıs 2020), https://apps.who.int/iris/bitstream/handle/10665/175556/9789241564984_eng.pdf;jsessionid=066FA8AC1 D5D4421B023452CB8D17636? sequence $=15$.

39 Michael J. Reiss, "Food, Smoking and Sex: Values in Health Education”, Values in Education and Education in Values, ed. J.Mark Halstead and Monica J.Taylor, (London: Routledge, 2005), 98.

40 Güneş, "Cinsel İstismar Olgusu ve Mahremiyet Eğitimi”, 63.

41 Özaslan - Gültekin Akduman, "Ailelerin Mahremiyet Eğitimine İlişkin Görüşlerinin İncelenmesi”, $3 / 1368$. 
"Bütün eğitimimiz adap odaklı olursa ayrıca bir mahremiyet eğitimine gerek kalmadığını düşünüyorum” (KKÖ 10).

Mahremiyet eğitimi ahlak/adap ilişkisini başka bir bakış açısıyla ifade eden görüşlere de rastlamak mümkündür. Örneğin bir öğretici mahremiyet hassasiyetine sahip insanların doğal olarak ahlak ve adaba da sahip çıkacağını, ona önem vereceğini şu şekilde ifade etmiştir; "Mahremiyet eğitimine önem verenlerin bu işlere de önem vereceğini düşünüyorum” (KKÖ 9).

Bazı öğreticiler mahremiyet eğitimi ile ahlak/adap eğitiminin aynı şey olduğunu vurgulamışlardır. Bununla ilgili bazı düşünceler şöyledir;

"Evet, çünkü mahremiyet eğitimi almış kişilerin ahlaki anlamda daha dikkatli hareket ettiklerini düşünüyorum” (KKÖ 1). “... Ahlak eğitimi almış bir insan karşıdaki insanın mahrem alanına saygı duyar” (KKÖ 2).

4-6 yaş Kur'an kursu öğreticilerine göre mahremiyet ile ahlakı/adabı ayrı ayrı şeylermiş gibi düşünmek doğru değildir. Onlara ahlakın daha geniş kapsamlı olduğunu ve mahremiyeti de kapsadığını dolayısıyla aralarında bir ilişki olduğunu düşünmektedirler.

Ahlak ve mahremiyetin amaçlarına bakıldığında iki olgunun da insanın saygın bir hayat yaşaması, birlikte yaşadığı insanların varlıklarını gözetmesi, önemsemesi, değer vermesi gibi amaçları olduğu söylenebilir. Bu yönüyle birbirini tamamlayan, birbirini kapsayan iki kavram ve olgudan bahsedilmektedir. Ancak kapsam olarak bakıldığında ahlakın daha geniş bir içeriğe sahip olduğu, mahremiyeti de içine aldığı ileri sürülebilir.

Mahremiyet eğitimi de bireyin özel alan ilkeleri oluşturmasında onu destekleyebilir. Bu ilkeler sayesinde kendisine ve başkalarına saygı duymayı da öğrenebilir. Kişiliğin gelişimi, değer becerilerinin artması ahlaken gelişen ve olgunlaşan insan olma noktasında ona önemli katkılar sunabilir.

\section{4. Öğreticilere Göre Çocuklara Mahremiyet Eğitimi Verilmesi}

“Çocuklara mahremiyet eğitimi verilmeli midir? Neden?" şeklinde sorulan soruda, öğreticiler bu eğitimin verilmesini savunmuşlardır. Öğretici görüşlerinden bazıları şöyledir;

"Kesinlikle evet. Çünkü korumasız varlık olan çocuk saf düşünceleri ile bilinçsiz yetiştiğinde her türlü istismara açık olarak yaşamaktadır” (KKÖ 1). “Çocuklara mahremiyet eğitimi verilmelidir. Çünkü çocuk öncelikle kendi özelinin farkına varır. Farkına vardı̆̆ı için başkasının özeline de saygı duyar. Nedenine gelince alışkanlıklar küçük yaşlarda başlar” (KKÖ 2). "Evet, verilmelidir çünkü küçük yaşlarda öğrenim yani değerler daha sonra normal olarak kabul görüyor. Kendilerini kötü emelli insanlara karşı korumak için de bilinçlendirilmeliler" (KKÖ 4).

Öğreticilerin tamamı büyük bir vurgu ile bu eğitimin çocuklara verilmesi gerektiğini vurgulamışlardır. Bu düşünce, bazı çalışmalarda ortaya çıkan öğrenci velilerinin istekleri ile de doğru orantılı olduğu görülmektedir. Konuyla ilgili bir çalışmada görüşlerine başvurulan tüm annelerin çocuklarına mahremiyet eğitimi 
verdikleri $^{42}$ belirtilmiştir. Bir başka araştırma sonuçlarına göre de okul öncesi öğretmenleri erken çocuklukta cinsel eğitimi desteklediklerini ifade etmişlerdir. ${ }^{43}$ Cinsel eğitimin gerekliliği de dâhil tüm sonuçlar birleştirildiğinde öğretmen olsun, öğretici olsun veya ebeveyn olsun, tüm paydaşların okul öncesi dönemdeki çocukların cinsel gelişimine uygun bir mahremiyet eğitimi almaları gerektiği fikrini paylaştıkları görülmektedir.

Görüşler incelendiğinde, baz1 4-6 yaş Kur'an kursu öğreticileri, mahremiyet eğitimi alan öğrencilerin, bu eğitim ile kendilerini kötü amaçli insanlara karşı koruma refleksi geliştirebileceklerine inandıkları, anlaşılmaktadır. Onlara göre bu eğitimin temel amacı insanların kendisi ve başkasının özeline saygı duymayı öğrenmek olsa da en önemli amacı çocuğun kendisini koruyabilmeyi öğrenmesidir.

4-6 yaş Kur'an kursu öğretici görüşlerinden hareketle, okul öncesi dönemdeki bir eğitim ile bu ister mahremiyet eğitimi olsun isterse başka bir eğitim olsun, çocuğun kendisini korumayı öğrenmesi tartışmalıdır ${ }^{44}$ ve bu noktayı tartışmak gerekir. Çocuktan bu anlamda beklenen davranış acaba onun gösterebileceği, gücünü aşan bir şey değil midir? Henüz bu yaşlardaki bir çocuğun trafikte karşıdan karşıya geçme konusunda koordinasyon, odaklanma vb. becerileri bile tam oluşmamışken kötü niyetleri algılayabilecek donanıma kavuşmasını beklemenin, çocuğun gelişim ödevleri ve eğitim sürecinin hassasiyeti bakımından gerçekçi olmadığı söylenebilir. Ayrıca mahremiyet eğitimini korunma amacıyla verilen bir eğitim şeklinde tek bir amaç ile ifade etmenin bu eğitimin kapsamı ve önemi açısından da yetersiz kaldığı ileri sürülebilir. Çünkü zikredilen hususiyetler ile birlikte, mahremiyet eğitimi, çocukta öz saygı, kişilik, sosyal ilişkiler geliştirmenin; sonraki süreçte kendisini, mahrem alanlarını korumanın bir hazırlık eğitimi olarak düşünmek gerekir.

\section{5. Öğreticilere Göre Mahremiyet Eğitimini Verme Zamanı}

4-6 yaş Kur'an kursu öğreticileri "Mahremiyet eğitimi ne zaman/hangi yaşlarda verilmelidir? Neden?" şeklindeki soruya ilişkin okul öncesi dönemin ve ailenin önemine işaret eden görüşler dile getirmişlerdir;

"Önce ailede başlayarak gerekli her alanda" (KKÖ 1). "Mahremiyet eğitimi çocuk çok küçükken başlamalıdır. Çocuk iki yaşında sütten kesilir. Çocuğun bezi başkalarının yanında değiştirilmesi” (KKÖ 2). "Vücudunu tanımaya başladığı zamandan sonra verilmelidir dört yaş olabilir” (KKÖ 3). "4-7 yaş aralığında önce anne baba tarafından ve okuldaki eğitimcileri tarafından verilmelidir” (KKÖ 4). "Küçük yaşlarda verilmesi gerekli çünkü bu bilinçaltına yerleştirmek lazım mahremiyetin farkındalığını anlamalı" (KKÖ 5). “Çocuk kendini bilmeye başladığı andan itibaren ona ait olan özel alanın bilmeli, ona

42 Özaslan - Gültekin Akduman, “Ailelerin Mahremiyet Eğitimine İlişkin Görüşlerinin İncelenmesi”, $3 / 1368$.

43 Kardeş - Güney Karaman, "Okulöncesi Öğretmenlerinin Çocuğun Cinsel Eğitimine İlişkin Görüşleri”, 1563.

44 Jill Duerr Berrick, “Sexual Abuse Prevention Education Is It Appropriate for the Preschool Child?", Children and Youth Services Review 11/2 (1989), 145. 
göre hareket etmelidir (3-4 yaş)" (KKÖ 6). "Mahremiyet eğitimi 4-6 yaş aralı̆̆ında verilmeye başlanmalıdır çünkü çocuk kendini ve çevresindekileri tanımaya başlar artık anne baba kardeş veya yakın çevresi dışındaki insanlarla iletişime geçmeye başlar" (KKÖ 7). “Gençlik çağına kadar yavaş yavaş verilmeli” (KKÖ 8). “Dediğim gibi bu eğitim ta ailede başlıyor. Çocuğun altını açtığımda ona dikkat ediyoruz. Küçük yaşlardan itibaren bunu öğreteceğiz onu öğreniyor bir yaş gerekirse ben doğduğu andan itibaren diyorum. Çocuk kendini korumayı da küçük yaştan itibaren öğrenmeli. Tuvalet eğitimini vermeye başladığımızda da bunun üzerinde özellikle durduk. Benim çocuğum başkaları ile tuvalete gitmez asla gitmez yani bunu öğrendi (KKÖ 9). “Önce aile sonra öğretmenler bunu vermeli. Buna Kur’an kursu ve anasınıfı öğretmenleri dahil" (KKÖ 10).

Mahremiyet eğitiminin yaşı ile ilgili farklı yaş aralıkları ifade edilse de ifade edilen tüm yaş aralıkları okul öncesi dönemi işaret etmektedir. Öğreticiler, erken dönemden itibaren çocuğun zihinsel ve bedensel gelişimine paralel olarak tedrici ve gerektiği kadar verilmesi gerektiğini ifade etmişlerdir. Çocuk ilk iki yaşı içerisinde cinsellikle ilgili sorular sorabilir ve cinsel organını keşfedebilir. ${ }^{45} \mathrm{Bu}$ dönem mahremiyet eğitiminin başlama dönemi sayılabilir. Ancak mahremiyet eğitimi için tuvalet eğitimi kritik bir dönemdir. Bu dönemde çocuğun bedensel gereksinimlerini kontrol etmeyi öğrenmesi onda başarı ve bağımsızlık duygusu ile birlikte sosyalleşme sürecinin çatışmalarını yansıtır. Çocuk, bu evrede çevrenin kendisinden neler beklediğini fark etmeye başlar. ${ }^{46}$

"Freud yaşamın ilk altı yılına denk gelen gelişim dönemlerinde geçirilen yaşantıların önemlerini vurgulayarak, o dönemde geçirilen yaşantıların izlerinin hiçbir zaman tümüyle yok olmadığını ve yetişkinlik yıllarında da davranışları etkilemeye devam ettiğini öne sürmektedir." ${ }^{47}$ Freud'a göre cinsel kimlik, 3-7 yaşları arasına gelen fallik dönemde gelişmeye başlar. Freud'a göre ilk gelişim dönemlerinde çocuğa gösterilen ilgi ve bakım, çocuğa verilen sevginin niteliği ve miktarı, yetişkinlik yıllarındaki kişiliğin belirleyicilerindendir. ${ }^{48}$

Erikson da sosyal çevrenin kişilik gelişimi üzerindeki etkilerinin çok olduğunu vurgular. ${ }^{49}$ O'na göre okulöncesi dönemde sağlanan uygun çevresel koşullar kendine güven, bağımsızlık, özerklik, girişimcilik gibi kişilik gelişimini olumlu yönde etkileyen duyguların kazanılmasında büyük önem taşır. ${ }^{50}$ Kentler de iyi bir gelişim için çocukların bedensel ilgiye, şefkate ve sevgiye gereksinimleri vardır, ${ }^{51}$ der. Bu açıklamalar, bireyin etkileşimde bulunduğu çevrenin olabildiğince düzenlenmesi/kontrol edilmesi

45 Duygu Çalışır, Cinsel Eğitim Çocukluktan Ergenliğe (İstanbul: Profil Yayınları, 2011), 29.

46 Çalışır, Cinsel Eğitim Çocukluktan Ergenliğe, 33-34; Münire Erden - Yasemin Akman, Eğitim Psikolojisi (Ankara: Arkadaş Yayınları, 2008), 83.

47 Erden - Akman, Eğitim Psikolojisi, 82.

48 Erden - Akman, Eğitim Psikolojisi, 83.

49 Erden - Akman, Eğitim Psikolojisi, 84.

50 Erden - Akman, Eğitim Psikolojisi, 87.

51 Helmut Kentler, Çocuğuma Nasıl Cinsel Eğitim Verebilirim?, çev. Gülderen Pamir (İstanbul: Turkuaz Yayınlar1, 2008), 65. 
gerektiğini, aile, okul gibi özel etkileşim alanlarında doğru yaşantıların kazandırılmasına yönelik ortamların oluşturulmasının zorunluluğunu göstermektedir. O halde kişilik gelişiminin bir öğesi olarak çocuklarda mahremiyet eğitimi, cinsel farkındalığın oluşmaya başladığı dönemden itibaren ve ihmal edilmeden verilmesi çocukların olumlu yönde etkileyeceği söylenebilir. Aksi takdirde gerekli eğitimin ihmal edilmesi, bireyin kişilik, din, ahlak gelişimini sekteye uğratarak onun ileriki zamanlarında bu eksikliği yaşamasına neden olabilir. ${ }^{52}$

Görüldüğü gibi küçük yaştan itibaren çocuklara doğru bir mahremiyet eğitiminin verilmesi kimlik ve kişilik gelişimi açısından çok önemlidir. Bunun için öncelikle anne baba olmak üzere bu eğitimin tüm paydaşlarının mahremiyet eğitimini nitelikli yapması için gerekli eğitimi alması gerekir. ${ }^{53} \mathrm{Bu}$ konuda programlar geliştirilebilir, yayın hizmetleri sunulabilir veya hizmet içi eğitim, seminerleri verilebilir.

4-6 yaş Kur'an kursu öğretici görüşlerinde aile vurgusu da çok önemli bir yer tutuyor. Ancak bu noktada eğitimde aileye vurgu yapmanın, ailenin çocuk için değerini hatırlatmanın önemli olduğu hatırlatmakla yetinilecektir. Bununla birlikte çocuğun ailesi ile hangi nitelikte bir birliktelik yaşadığı da son derece önemli görülmelidir.

\section{6. Öğreticilere Göre Mahremiyet Eğitiminde Yer Alması Gereken Konular}

"Mahremiyet eğitiminde hangi konular yer almalıdır?" sorusuna öğreticilerin mahremiyet eğitiminde yer alması gereken konularla ilgili hem bireysel ve hem de toplumsal davranış örüntülerine işaret ettikleri görülmektedir. Bazı görüşler şöyledir;

"Kişiye özel gelen her konu” (KKÖ 8). "Cinsel eğitim, sayg1, terbiye” (KKÖ 2). "Erkek, dişi ayrımı, özel alanlar dokunulması yasak bölgeler gibi” (KKÖ 3). "Bütün uzuvlarımızla birlikte bize ait olan şeylerin özel olduğu anlatılmalı” (KKÖ 4). "Önce çocuğa vücudu tanıtılmalı hassas bölgeleri öğretilmeli” (KKÖ 5). “Cinsel konular, zarafet, nezaket, ahlak ve edep kuralları insanlarla olan ilişkileri düzenleme” (KKÖ 6). "Kişiye özel gelen her konu” (KKÖ 8). "Mahrem saklamak demek. Sadece kadın erkek demek değil. Hayatın tamamında bu duygunun yer alması gerekiyor. Bazı şeyleri gizli yaşamak gerekiyor her şeyin ortada yaşanması çok çirkin geliyor bana. Bu ortaya dökülmeyi küçüklükten itibaren öğreniyoruz. Neyi saklayacağımızı bilemiyoruz. Bazen konuşulan bir konu mahremdir. Bazen kıyafet mahremdir. Bakışlar bile mahrem olabilir" (KKÖ 10).

4-6 yaş Kur’an kursu öğretici görüşlerine göre mahremiyet eğitiminde bireysel anlamda insan gelişimini destekleyen konuların yer alması gerektiğini ileri sürümüşlerdir. Onlara göre çocuğun vücudunu, mahrem olan yerlerini, mahrem konuları tanıması; kişiye ait özel her şeyi mahremiyet eğitiminin konuları arasında yer almalıdır. Bir başka ifade ile mahremiyet bunları öğretim konusu etmelidir. Öğreticiler, toplumsal anlamda ise mahremiyetin tüm insan ilişkilerini ilgilendiren son derece geniş bir

53 Özaslan - Gültekin Akduman, “Ailelerin Mahremiyet Eğitimine İlişkin Görüşlerinin İncelenmesi.” 3/1368. 
kapsama sahip olduğunu düşünmektedirler. Bundan dolayı ahlakın konu edindiği nezaket, zarafet, saygı gibi insani ve ahlaki değerler da mahremiyet eğitiminin yer alması gereken konular arasında öğreticiler tarafından belirtilmiştir.

Mahremiyetin kapsamı genişlediğinde bu eğitimi genel eğitimin, ahlakın, adabın bir şubesi olarak görmek gerekir. Nitekim bir öğreticiye doğrudan "o zaman mahremiyet eğitimi genel eğitimin bir parçası gibi düşünülebilir mi?” sorusuna öğretici "Tabii ki. Hayatın içinde olan ve mutlaka alınması gereken, alanın içinden alınamayacak bir şey, bir erdem olarak görüyorum" (KKÖ 9).

Mahremiyet eğitimin kapsamını ahlak ve adap ile ilişkilendiren görüşler yine bu tema altında da kendisini göstermektedir.

"Mesela kapı vurma adabı. Çocuk kapıyı çalmadan içeri girmez biz de onun odasını izin almadan girmeyiz. Onlar yer almalıdır" (KKÖ 9). "Odaya izinsiz girmeme dedik tuvalet dedik başka ne diyebiliriz? Büyüklere konuştuklarımız da çocuklara konuştuklarımız farklı olmalı diye düşünüyorum ya da eşimle konuştuklarımla çocuğunla konuştuklarım de farklı olmalı" (KKÖ 9).

Bazı öğreticiler ise mahremiyet eğitiminin kapsamını çocuğun etkileşimde bulunduğu her şey olarak gördükleri anlaşılmaktadır. Bunu ifade eden bir görüşşöyledir;

"Ben bazı çocuk oyuncaklarından da hoşlanmıyorum. Çünkü bu oyuncaklar mahremiyete uygun olmuyor. Örneğin Barbie bebekler. Bu bebeklerde kıyafet sorunu var" (KKÖ 10).

Bu görüşe göre çocukların bazı oyuncakları, oyuncakların kıyafetleri mahremiyet anlayışına uymadı̆̆ı için, eğitim kapsamında titizlikle seçilmesi gerekiyor. Öğretici burada önemli bir noktaya temas etmektedir. Çocuğun oyuncakları, izlediği filmler, animasyonlar, okuduğu veya dinlediği kitaplar, masallar, hikâyeler vs. hepsi yerine göre birer eğitici rolündedir. Öğreticilerin bunlara dikkat etmeleri gerekmektedir. Söz konusu öğreticiye konuyu açmak amaçlı "bu da mahremiyet eğitiminin bir parçası mıdır?" şeklinde soru yöneltilmiş ve "Evet eğitim buradan başlamalıdır. Çocuğun seyrettiği filmler okuduğu kitaplar hepsi buna girer" (KKÖ 10) şeklinde cevap alınmıştır. Cinselliğin insan yaşamının önemli bir parçası olduğu yadsınamaz. Ancak; dijital oyunların, filmlerin, oyuncakların, giysilerin, müzik videolarının pazarlanmasında cinselliğin sıklıkla ticari amaçlı kullanıldığ1 ${ }^{54}$ dolayısıyla istismar edildiği unutulmamalıdır. Tam da bu noktada mahremiyet eğitiminin önemi bir kez daha ortaya çıkmaktadır, denilebilir.

Benzer bir araştırmaya göre okul öncesi öğretmenler cinsel eğitim dersinin içeriğinin çocukların gelişim düzeyine uygun olması, ihmal ve istismara yönelik bilgi içermesi ve çocukların çevresine (aile, öğretmen vb.) yönelik bilgilendirme içermesi gerektiğini ifade etmişlerdir. ${ }^{55}$ Ancak iki araştırma karşılaştırıldığında OÖKK öğretici-

54 Kardeş - Güney Karaman, “Okulöncesi Öğretmenlerinin Çocuğun Cinsel Eğitimine İlişkin Görüşleri", 1555.

55 Kardeş - Güney Karaman, “Okulöncesi Öğretmenlerinin Çocuğun Cinsel Eğitimine İlişkin Görüşleri”, 1563. 
lerinin mahremiyet eğitiminde yer alması gereken konularla ilgili daha geniş bir yelpaze oluşturdukları anlaşılmaktadır. Belki de bu sonuç cinsel eğitime kıyasla mahremiyet eğitiminin kapsamıla da açıklanabilir.

\section{7. Öğreticilere Göre Mahremiyet Eğitiminin Önemi}

4-6 yaş Kur’an kursu öğreticilerine "Çocuklara erken yaşlarda mahremiyet eğitimi vermek hangi katkıları sağlayabilir?" sorusu soruldu. Onların bazı cevapları aşağıdaki gibidir;

"Bilinçli yetiştiğinde kendini tehlikelerden koruyarak travma yaşayacak olaylardan uzak kalmasını sağlar” (KKÖ 1). "Çocuk mahremiyet eğitimi ile ahlaki değerlere sahip çıkar. Maalesef hocam bu tür şeyler daha önceden verilseydi çok affedersiniz hocam bu taciz, tecavüz olayları, istismar olayları yaşanmazdı veya şiddet eğilimi olmazdı. İnsan maalesef bilinçlenmeden. Şu an gerçekten her gün televizyonu açtığımızda duyarsızlaştık. Biz bile üzülmüyoruz bu olaylara. İşte bugün bu kadın vurulmuş diyoruz. Sıradanlaşıyor. Oysaki bilsek, bilinçlensek böyle olur mu? İşte burada şu yatıyor" (KKÖ 9). "Korur hocam. Vücudun kendisine ait bir şey olduğunu, mahrem olduğunu başkasının dokunmaması gerektiğini; özellikle baba ve dede dişındakilerin dokunmaması gerektiğini bilmeli. Ama korkutmadan ve ürkütmeden. Çünkü korkutursak ilerde evlilik hayatında sıkıntılar yaşayabilir" (KKÖ 10).

Öğretici görüşlerine göre mahremiyet eğitiminin en önemli yararı çocukları çeşitli tehlikelerden korumasıdır. Onlara göre bu eğitim çocukların vücutlarının kendilerine ait olduğunu; özel bölgelerine kendinden başkasının kimsenin dokunmamayı öğreteceğine inandıklarını belirtmişlerdir. Çocuklara erken yaşlarda mahremiyet eğitimi öneminin son derece vurgulandığı öğretici görüşlerinden anlaşılmaktadır. Başta çocukların yüz yüze kalabileceği bazı cinsel içerikli mağduriyetlere karşı bu eğitimin önemli katkılar sağlayacağı ifade edilmiştir.

Bazı 4-6 yaş Kur'an kursu öğreticileri ise mahremiyet eğitiminin çocuğun ahlak ve kişilik gelişimine katkıda bulunacağını ileri sürmüşlerdir;

"Sınırlarını bilerek yetişen çocuk her durumda saygılı olmayı bilir ilişkilerinde hakkı hukuku gözetir" (KKÖ 4). "Erken yaşta mahremiyet eğitimi verilen bireyin kişisel gelişiminin daha sağlıklı olacağını düşünüyorum” (KKÖ 7). "Ahlakî kurallar kısmen yerleşmiş olur” (KKÖ 8. "Kişilik gelişimi ve duyguları yönetme noktasında katkı sağlar” (KKÖ 6). "Birey erken yaşta kendini tanır" (KKÖ 5)" "Kendisini tanır, kendisini sever. İyi bir kişilik olmasını sağlar” (KKÖ 10). "Çocuklar mahremiyet eğitimini bilirlerse kendilerini korurlar geliştirirler. Güzel olur diye düşünüyorum” (KKÖ 9). "Evet, Kur'an kurslarında eğitimler yapıyoruz ama bu eğitimin genel eğitime paralel gitmesi gerekmez mi? örneğin Kur'an kursunda yarattığımız dünya ile gerçek dünyanın birbirinden tamamen kopuk olmaması gerekmez mi sizce yani din eğitimi için de bunu söyleyecek herkes. Bu eğitim ilk önce insanın özgüvenini sağlar. Ben kimliği gelişiyor bana ait duygusu kendini koruma içgüdüsü gelişiyor. Çünkü aksi takdirde büyük s1kıntı Allah korusun” (KKÖ 10). "Çocuk daha küçük yaşta örtünmesi gereken yerleri 
örter. Edep hayâ bilinci oluşur" (KKÖ 2). "Kişiliğinin temelleri atılması için” (KKÖ 6). "Kendini koruması ve başkalarına zarar vermemek üzere duygularını yönetebilmesi için” (KKÖ 6). "Okulun görevi değişik materyallerle bu eğitimi vermek ve çocukta özgüven oluşturmak” (KKÖ 5).

Öğreticilere göre mahremiyet eğitiminin önemi çocuğun birçok tutumuna doğrudan etkide bulunabilir. Onlara göre çocuk bu eğitim ile birlikte saygılı olmak, hak hukuk gözetmek, kendini tanımak, kimlik ve kişilik geliştirmek, kendini korumak gibi ahlaki beceriler kazanabilir. Hatta çocukların empatik becerilerine bile etkide bulunabilir. Bir öğretici “Çocuk bir empati becerisi kazanabilir mi?” şeklindeki soruya koşullu bir cevap vermiştir: "İnşallah. Doğru verilirse kazandırır” (KKÖ 10).

Görüldüğü gibi 4-6 yaş Kur’an kursu öğreticilerinin mahremiyet eğitiminden beklentileri oldukça yüksek görünmektedir. Çocuğun gelişimine çok yönlü etkilerinin olacağını, kendilerine koruma, kendilerine güven duyma ile birlikte, sorumluluk geliştirme, insanlara sevgi ve saygı ile bakma, başkalarının duygularını anlama bağlamında bu eğitimin çok işlevsel olabileceği konusunda oldukça iyimser oldukları anlaşılmaktadır. Çeşitli araştırmalar da mahremiyet eğitiminin çocukların gelişimindeki önemini vurgulamıştır. ${ }^{56}$

Çocuklara kazandırılması gereken ilk üç değer sıralamasında okul öncesi öğretmenleri saygı, sorumluluk, sevgi, hoşgörü, paylaşma, dürüstlük, yardımlaşma, iş birliği şeklinde sıralama yaptıkları görülmüştür. Öğretmenler, bu değerlerin diğer değerler için temel oluşturacağını, bu değerlerin çocukların sonraki yaşamlarını kolaylaştırması ve toplumsal düzen için gerekli olduğunu belirtmişlerdir. ${ }^{57}$ Mahremiyet eğitiminin sevgi, saygı ve sorumluluk temelli bir eğitim olduğu söylenebilir. Bu eğitim çocukların insanlara sevgi ile yaklaşmanın, onların ve kendilerinin özeline saygı ile yaklaşmanın sorumluluğunu geliştirebilir. Bu yönüyle değerler eğitiminin önemli bir

56 Bu konuda bk. Nagehan İpek, İslam’in Mahremiyet Algısı Işığında Mahremiyet Eğitiminin Çocuk Cinsel İstismarını Önlemedeki Rolü (Erzincan: Erzincan Binali Yıldırım Üniversitesi, Sosyal Bilimler Enstitüsü, Yüksek Lisans Tezi, 2020); Zeynep Türkyllmaz 3-6 Yaş Grubu Çocuğu Olan Ebeveynlerin Mahremiyet Eğitimine Dair Bilgilerinin İncelenmesi (Üsküdar Örneği) (İstanbul: Üsküdar Üniversitesi, Sağllk Bilimleri Enstitüsü, Yüksek Lisans Tezi, 2019); Semiha Çakır, 4-6 Yaş Aralğındaki Çocuklara Mahremiyet Eğitimi Verilmesinde Din Eğitimin Rolü” (Sivas Örneği) (Sivas: Cumhuriyet Üniversitesi, Sosyal Bilimler Enstitüsü, Yüksek Lisans Tezi,2015); Feyza Ünal, Çocuk Cinsel İstismarnda Cinsel Kimlik Ve Mahremiyet Eğitiminde Rehberlik Öğretmenlerinin Rolü (Yalova: Yalova Üniversitesi Sosyal Bilimler Enstitüsü, Yüksek Lisans Tezi, 2019); Habibe Çalışkan, Okul Öncesi Dönemde Çalışan Öğretmenlerin Mahremiyet Eğitimi Konusunda Bilgi Düzeylerinin Belirlenmesi (Konya: Necmettin Erbakan Üniversitesi, Eğitim Bilimleri Enstitüsü, Yüksek Lisans Tezi, 2019); Emine Kürek, Cinsel Kimlik Gelişiminde Din Eğitiminin Rolü (Samsun: Ondokuz Mayıs Üniversitesi, Sosyal Bilimler Enstitüsü, Yüksek Lisans Tezi, 2012); Hüseyin Emre Duran, Değerler Eğitimi Bağlamında Mahremiyet Eğitimi (Samsun: Ondokuz Mayıs Üniversitesi, Sosyal Bilimler Enstitüsü, Yüksek Lisans Tezi, 2018); Diler, "Mahremiyet Eğitimi ve Önemi”; Güneş, "Cinsel İstismar Olgusu ve Mahremiyet Eğitimi”; Gündoğdu, "Mahremiyet Eğitiminin Temeli İnsanlık Şerefi: Ailenin Mesuliyetleri”; İder, "Yetişkinlerde Mahremiyet Algısının Kaynağına İlişkin Nitel Bir Araştırma”; Özaslan - Gültekin Akduman, "Ailelerin Mahremiyet Eğitimine İlişkin Görüşlerinin İncelenmesi."

57 Hülya Gülay Ogelman - Hatice Sarıkaya, "Okul Öncesi Eğitimi Öğretmenlerinin Değerler Eğitimi Konusundaki Görüşleri: Denizli İli Örneği.” Sakarya Üniversitesi Eğitim Fakültesi Dergisi 29 (2015), 93. 
paydaşı olarak görülebilir. Deniz, yaptığı deneysel bir çalışmada, okuldaki değerler eğitimi programının çocukların duyguları düzenleme, okul hazır bulunuşluğu, sosyal güven ve duygusal gelişimlerini etkilediğini ${ }^{58}$ ifade etmiştir.

Okul öncesi öğretmenlerin cinsel eğitim anlayışlarını inceleyen bir nitel araştırmada ise bazı öğretmenler cinsel eğitimi çocuğa mahremiyet eğitimi vermek şeklinde ifade etmişlerdir. ${ }^{59}$ Bu çalışmadan elde edilen bazı sonuçlar mahremiyet eğitiminin önemine doğrudan işaret etmektedir. Aynı araştırmaya göre oö öğretmenlerin cinsel eğitimin amaçları için öngördüğü ile OÖKK öğreticilerinin mahremiyet eğitiminin amacı ve önemine ilişkin söyledikleri arasında bir paralellik görülmektedir. ${ }^{60}$ Güneş ülkemizde artan cinsel istismar olaylarının mağdur kitlesinin çoğunlukla çocuklar ve kadınlar olduğunu ileri sürmektedir. Bu tür problemlerin suça dönüşmeden engellenmesi, mahremiyet gibi değerlerin kazandırılması ile mümkün olduğunu iddia etmektedir. ${ }^{61} \mathrm{Bu}$ açıklamalar ile öğreticilerin mahremiyet eğitiminin önemine ilişkin beklentisinin örtüştüğü görülmektedir. Ancak okul öncesi çocuklar için cinsel istismarın önlenmesi eğitimi kolay değildir. Harcanan para ve çabaya rağmen 3-5 yaş arasındaki çocukların kendilerini cinsel istismardan korumayı ne kadar ve nasıl öğrenebilecekleri ${ }^{62}$ ciddi bir soru olarak karşımızda durmaya devam etmektedir.

Son olarak mahremiyet eğitimi sürecinin önemini hatırlatmak gerekir. Bir öğreticinin; “Ama korkutmadan ve ürkütmeden. Çünkü korkutursak ilerde evlilik hayatında sıkıntılar yaşayabilir” (KKÖ 10) ikazı mahremiyet eğitiminin içeriği kadar eğitim sürecinin de hassasiyetine dikkat çekmesi açısından önemli görülmektedir. Yine bu meyanda bir öğreticinin "İnşallah. Doğru verilirse kazandırır” (KKÖ 10) şeklinde belirttiği gibi bu eğitimin nasıl yapılması gerektiği üzerinde düşünmekte büyük yarar olduğu söylenebilir. Bu noktada eğitimcilere büyük bir iş düşmektedir.

Yetişen neslin ahlakı, adabı, mahremiyeti vs. öğrenmede eğitimcilerin çok önemli misyonları vardır. Eğitimciler şartların kendi arzularının doğrultusunda oluşmasını beklemeden ${ }^{63}$ her şartta insani niteliklerin en iyi şekilde tezahürüne katkıda bulunabilirler. Böylece mahremiyet eğitiminin gerçekleşmesi için bir firsat yakalanmış olur. Mahremiyet eğitimi çocukların sosyal gelişimini destekleyerek öğrenme ortamlarının güzelleşmesine de katkı sağlayabilir. Bununla birlikte mahremiyet eğitimi, çocuğun başkasının mahreminin ne olduğunun öğrenmesine katkı

\footnotetext{
58 Ayşe Öztürk Samur, Değerler Eğitimi Programının 6 Yaş Çocuklarının Sosyal ve Duygusal Gelişimlerine Etkisi (Konya: Selçuk Üniversitesi, Sosyal Bilimler Enstitüsü, Doktora Tezi, 2011), 113.

59 Kardeş - Güney Karaman, “Okul Öncesi Öğretmenlerinin Çocuğun Cinsel Eğitimine İlişkin Görüşleri”, 1558.

60 Kardeş - Güney Karaman, “Okul Öncesi Öğretmenlerinin Çocuğun Cinsel Eğitimine İlişkin Görüşleri”, 1559.

61 Güneş, "Cinsel İstismar Olgusu ve Mahremiyet Eğitimi”, 62.

62 Berrick, “Sexual Abuse Prevention Education Is It Appropriate for the Preschool Child?”, 145.

63 Muhammet Şevki Aydın, Cumhuriyet Döneminde Din Eğitimi Öğretmeni Yetiştirme ve İstihdamı (Ankara: DEM Yayınları, 2005), 32.
} 
sağlayabilir; bu katkının insan ilişkilerindeki izdüşümlerini görmesine neden olabilir. Mahremiyet eğitimi çocuğa, kötülüğe maruz kalmamak ile birlikte kötülüğe neden olmamaya, taciz eden taraf olmamaya da katkısı olabilir. Ayrıca çocuk bu eğitim vesilesiyle, büyüdüğünde dedikodu yapmaktan, yalan söylemekten, giybet etmekten, başkasının yanlış ve eksikliklerini ifşa etmekten uzak durmayı da öğrenebilir.

\section{Sonuç}

Araştırmamıza katılan tüm bireyler kadındır. Bunlardan 9'u evli birisi bekârdır. Bekâr öğretici dışında kalanların hepsi 35 yaş ve üstüdür. Bu yaş dönemi öğretmenlik, hayat, çocuk yetiştirme tecrübesi olarak bir olgunluğun işareti olarak görülmüştür. Buna göre çalışma grubunun deneyimli, kendini rahat ifade edebilecek potansiyele sahip bireylerden oluştuğu ileri sürülmüştür. Ancak araştırmaya katılan öğreticilerin sadece 3 tanesi lisans mezunu olduğunu ifade etmiştir. Diğerlerinin tamamını ön lisans mezunu olduğu görülmüştür. Öğreticilerin çoğunun ön lisans mezunu olması pedagojik formasyon yeterliği açısından son derece sorunlu görüldüŭgü belirtilmiştir. Bu bakımdan 4-6 yaş Kur'an kursu gibi önemli bir eğitim döneminde bu eksikliğin ciddi sonuçlarının olabileceği söylenebilir.

4-6 yaş Kur'an kursu öğreticilerinin görüşleri incelendiğinde, onların mahremiyet kavramının kapsamını geniş tuttukları anlaşılmaktadır. Onlara göre bu kavram başta insan kişiliği olmak üzere, ahlak, adap, din, toplum, eğitim, aile, okul ve bu kurumlardaki davranışların neredeyse tamamıla ilişkilendirilebilen geniş bir içeriğe sahiptir. Bu bakımdan mahremiyetin öğrenme konusu yapılması çocukların gelişimlerine çok yönlü bir katkı yapabilir.

Çalışmada elde edilen verilerden hareketle 4-6 yaş Kur'an kursu öğreticileri arasında mahremiyet eğitiminin tanımına ilişkin ortak bir anlayış görülmemiştir. İlgili literatürde de benzer bir durumun olduğu; alan yazında henüz üzerinde anlaşılmış bir mahremiyet eğitimi tanımına ihtiyaç duyulduğu anlaşılmaktadır. Mahremiyetin kapsamlı bir tanımının yapılmasının literatüre bir zenginlik katabileceği gibi alanda çalışanlara da yardımcı olacă̆ı söylenebilir.

4-6 yaş Kur'an kursu öğreticileri cinsel eğitim ile mahremiyet eğitimi arasında bir ilişki olduğunu ancak mahremiyet eğitiminin daha geniş kapsamlı ve ihtiyaç karşllamaya daha uygun olduğunu düşünmektedirler. Öğreticiler mahremiyet eğitiminin doğrudan ahlak ve adap ile ilişkilendirilmesi gerektiğini düşünmüşlerdir. Bazı görüşlerde ise ahlak veya adap eğitimi yapmanın çocuğun mahremiyet algısı için yeterli olabileceği ileri sürülmüştür. Ancak mahremiyet ile ahlak ve adap arasında önemli biri ilişki olmasına rağmen mahremiyet eğitiminin ahlak ve adaptan ayrı özel kazanımları vardır. Bu kazanımların öğrenciler tarafından yaşantıya dönüştürülmesi nitelikli bir öğrenme süreci ile mümkündür.

Öğreticiler çoğunlukla mahremiyet eğitimini ahlak eğitimiyle bir şekilde ilişkilendirmişlerdir. Bu da mahremiyet eğitiminin geniş kapsamlı bir ahlak eğitimi olarak anlaşıldığını göstermektedir. Ayrıca mahremiyet eğitimi kazanımları bakımından ahlak eğitimine katkıda bulunabilme gücüne sahiptir. Böylece öğretici görüşlerinden 
hareketle insan öğrenmeleri arasında geçişken bir yapı olduğu anlaşılmaktadır. Mahremiyet konusunda öğrendiklerimizin diğer öğrenmeleri; diğer öğrenmelerin de mahremiyet ile ilgili olanları etkilemektedir.

Öğreticilere göre mahremiyet eğitimi, çocukların mutlaka alması gereken bir eğitimdir. Öğretcilerin bu konuda tam bir fikir birliği içerisinde oldukları görülmüştür. Bu eğitim için öncelikli kurumun aile olduğu çalışmaya katılan öğreticilerce belirtilmiştir. Ailede alınan eğitimin okuldaki eğitime önemli katkılar sunduğu, öğretmenlerin işini kolaylaştırdı̆̆ı belirtilmiştir. Öğreticilerin mahremiyet eğitimi ve ailenin bu eğitimdeki rolü konusunda tam bir fikir birliği içerisinde olmaları ailede mahremiyet eğitiminin neliği üzerinde düşünmeyi zorunlu k1lmaktadır.

Öğreticiler okulöncesi dönemin önemine binaen mahremiyet eğitiminin bu dönemde başlaması gerektiğini belirtmişlerdir. Bu görüş literatüre uygun görülmüştür. Çocuk tuvalet eğitimi ile fark etmeye başladığı mahremiyeti sonraki dönemlerde çeşitli sorular sorarak, cinsiyet ile ilgili merakını belli etmeye başlar. Çocuğun bu minvalde sorduğu sorular ve bu konuyla ilgili merakı mahremiyet eğitimin yapılmasını gerekli kılan önemli etmenlerdir. Buna göre çocuğun mahremiyet eğitimi ihtiyacının görmezlikten gelinmesi veya ertelenmesi sağlıklı bir yaklaşım değildir. Yapılması gereken çocuğun gelişimine ve ihtiyacına uygun bir eğitim yapmak; eğitim kurumlarında nitelikli bir öğrenme ortamı oluşturmaktır.

Çalışmadan elde edilen verilerden hareketle öğreticiler, önemine binaen, mahremiyet eğitiminde öncelikle çocukların özel bölgelerini tanıtma, tuvalet eğitimi, izin isteme adabı ve tanımadıklarına karşı çocuğun nasıl davranacağı gibi konuların yer alması gerektiğini belirtmişlerdir. Bu kazanımlar, çocukların kendilerini tanıma ve koruma, ihtiyaçlarını iyi bir şekilde karşılama; böylelikle sosyalleşme anlamında önemlidir.

Veri toplama aracı ile ilgili olarak şöyle bir bilgiye ulaşılmıştır. Ne kadar iyi hazırlanmış olursa olsun katılımcıların mülakat formları yoluyla paylaştıkları bilgilerin yüz yüze görüşme ile elde edilen bilgilerden nicelik olarak daha az ve nitelik olarak daha sığ olduğu müşahede edilmiştir.

\section{Öneriler}

4-6 yaş Kur'an kursu öğretici görüşleri çerçevesinde yapılan bir çalışma olarak, bunun ileriye ve diğer öğretim kurumlarına dönük önemli projeksiyonlar sunduğu düşünülmektedir. Bu bakımdan söz konusu çalışmaya bağlı olarak şu önerilere yer verilmiştir:

Başta okulöncesi eğitim kurumları olmak üzere diğer tüm kurumlarda görev yapmakta olan öğretmen ve öğreticilere dönük, mahremiyet eğitimi temalı yeni, farklı alan çalışmaları yapılabilir. Bu tür çalışmalar nitelikli, bilimsel karşılaştırmalar yapmak için önemli veriler sunabilir. 
Din eğitimi biliminin verileri doğrultusunda yapılan bu çalışmadan hareketle, mahremiyet eğitimi konusunda farklı akademik çevrelerin de bu konu üzerinde, çeşitli boyutlarıyla çalışmalar yapması önerilebilir. Bu tür çalışmalar farklı bir bakış açısı geliştirmek ve disiplinlerarası çalışmalar yürütmenin yollarını da açabilir.

4-6 yaş Kur'an kurslarında çalışan öğreticilerin mahremiyet ve eğitimine ilişkin görüşlerinden hareketle, hizmet öncesi eğitim programlarında mahremiyet eğitimine duyulan ihtiyacı ortaya koymaktadır. Bundan dolayı erken çocukluk eğitiminin her kademe ve kurumunda çalışan öğretmen ve öğreticilere planlı ve programlı bir mahremiyet eğitimi verilmesi, bu eğitimin öğretim programlarına dâhil edilmesi; bu minvalde öğretmenlere cinsel gelişim; olası çocuk ihmal ve istismar durumlarında nasıl bir yol takip edeceklerine ilişkin gerekli eğitimlerin verilmesi önerilebilir. $\mathrm{Bu}$ bakımdan ilahiyat lisans veya ön lisans programlarında mahremiyet eğitimi dersi önerilebilir. Böylece öğreticilerin hizmet öncesi eğitimle bu konudaki eksiklikleri tamamlanabilir. İkinci bir yol olarak da öğreticilerin mahremiyet eğitimindeki bilgi ve uygulama eksiklikleri hizmet içi eğitim yoluyla giderilebilir. Böylece öğretmenlerin bilgi ve uygulama becerilerinde ortak bir anlayış kazanmalarının önü açılmış olur.

\section{Etik Beyan / Ethical Statement}

Yazar / Author
$\mathrm{Bu}$ çalışmanın hazırlanma sürecinde bilimsel ve etik ilkelere uyulduğu ve yararlanılan tüm çalışmaların kaynakçada belirtildiği beyan olunur/It is declared that scientific and ethical principles have been followed while carrying out and writing this study and that all the sources used have been properly cited.

Ramazan Diler

\section{Kaynakça}

Akyürek, Süleyman. Din Öğretimi. Ankara: Nobel Yayınları, 2. Basım, 2010.

Aybey, Salih. "4-6 Yaş Grubu Kur’an Kurslarının Eğitim-Öğretim Faaliyetleri ve Problemleri (Zonguldak İli Örneği)”. Bülent Ecevit Üniversitesi İlahiyat Fakültesi Dergisi 6/2 (Aralık 2019), 207-240. https://doi: 10.33460/beuifd.598401

Aydın, Muhammet Şevki. Bir Din Eğitimi Kurumu Olarak Kur'an Kursu. Ankara: DỉB Yayınları, 1. Basim 2008.

Aydın, Muhammet Şevki. Cumhuriyet Döneminde Din Eğitimi Öğretmeni Yetiştirme ve İstihdamı. Ankara: DEM Yayınları, 2005.

Bacanlı, Hasan. Gelişim ve Öğrenme. Ankara: Nobel Yayınları, 8. Basım, 2004.

Bağlı, Mazhar. Modern Bilinç ve Mahremiyet. İstanbul: Yarın Yayınlar, 2011.

Başaran, İbrahim Ethem. Eğitim Psikolojisi. Ankara: Gül Yayınevi, 5. Basım, 1996.

Berrick, Jill Duerr. "Sexual Abuse Prevention Education Is It Appropriate for the Preschool Child?". Children and Youth Services Review 11/2 (1989), 145-158. https://doi.org/10.1016/ 0190-7409 (89)90030-3 
Bilgin, Beyza. Eğitim Bilimi ve Din Eğitimi. Ankara: Yeni Çizgi Yayınları, 1995.

Bilici, Ali Baz. “Din Eğitiminin İlk Temelleri: Erken Çocuklukta Din”. Dokuz Eylül Üniversitesi İlahiyat Fakültesi Dergisi 43 (2015), 65-87. https://doi.org/10.21054/deuifd.281886

Büyüköztürk, Şener. vd. Bilimsel Araştırma Yöntemleri. Ankara: Pegema Yayıncıllk, 2008.

Çakır, Semiha. 4-6 Yaş Aralı̆ı̆ndaki Çocuklara Mahremiyet Eğitimi Verilmesinde Din Eğitimin Rolü” (Sivas Örneği). Sivas: Cumhuriyet Üniversitesi, Sosyal Bilimler Enstitüsü, Yüksek Lisans Tezi, 2015. https://doi.org/10.33437/ksusbd.556576

Çalışır, Duygu. Cinsel Eğitim Çocukluktan Ergenliğe. İstanbul: Profil Yayınları, 2011.

Çalışkan, Habibe. Okul Öncesi Dönemde Çalışan Öğretmenlerin Mahremiyet Eğitimi Konusunda Bilgi Düzeylerinin Belirlenmesi. Konya: Necmettin Erbakan Üniversitesi, Eğitim Bilimleri Enstitüsü, Yüksek Lisans Tezi, 2019.

DİB, Kur’an Kursları Öğretim Programı (4-6 Yaş Grubu). Ankara: 2018.

Diler, Ramazan. “Mahremiyet Eğitimi ve Önemi”. Gaziosmanpaşa Üniversitesi İlahiyat Fakültesi Dergisi 2/1 (2014), 69-98.

Duran, Hüseyin Emre. Değerler Eğitimi Bağlaminda Mahremiyet Eğitimi. Samsun: Ondokuz Mayı Üniversitesi, Sosyal Bilimler Enstitüsü, Yüksek Lisans Tezi, 2018. https://doi.org/10.31592/ aeusbed. 337602

Erden, Münire - Akman, Yasemin. Eğitim Psikolojisi. Ankara: Arkadaş Yayınları, 2008.

Gün, Ayşegül. “Veli ve Öğretici Görüşleri Doğrultusunda 4-6 Yaş Grubu Kur'an Kursu Eğitimi: Samsun İli Örneği”. Amasya Üniversitesi İlahiyat Fakültesi Dergisi 7 (Aralık 2016), 33-66. https://doi. org/10.18498/amauifd.282862

Gündoğdu, Yusuf Bahri. "Mahremiyet Eğitiminin Temeli İnsanlı Şerefi: Ailenin Mesuliyetleri”. ODÜ Sosyal Bilimler Araştırmaları Dergisi (ODÜSOBİAD) 7/2 (2017), 387-394.

Güneş, Adem. “Cinsel İstismar Olgusu ve Mahremiyet Eğitimi”. İnsan ve Toplum 7/2 (2017), 4570. https://doi.org/10.12658/human.society.7.14.M0206

Güneş, Adem. Nezaket ve Zarafet İçin Mahremiyet Eğitimi. İstanbul: Timaş Yayınları, 2015.

El-Feyyûmî, Ahmed b. Muhammed. el-Miṣbâhu'l-münîr fi garîbi'ş-şerhi'l-kebîr. Beyrut: Dârü'l-Kütübi'l-ilmiyye, ts.

İder, Saadet. "Yetişkinlerde Mahremiyet Algısının Kaynağına İlişkin Nitel Bir Araştırma". Marife 19/1 (2019), 109-122. https://doi.org/10.33420/marife.534191

İpek, Nagehan. İslam'in Mahremiyet Algısı Işığında Mahremiyet Eğitiminin Çocuk Cinsel İstismarını Önlemedeki Rolü. Erzincan: Erzincan Binali Yıldırım Üniversitesi, Sosyal Bilimler Enstitüsü, Yüksek Lisans Tezi, 2020. https://doi.org/10.31123/akil.460160

Karasu, Tecelli. "Kur’an Kursu Öğreticilerine Göre Okul Öncesi Dönemde Din Eğitimi: Muş İli Örneği”. İlahiyat Tetkikleri Dergisi 1/51 (Haziran 2019), 483-484. 479-500. https://doi: 10.29288/ ilted.495961

Kardeş, Servet - Güney Karaman, Neslihan. “Okul Öncesi Öğretmenlerinin Çocuğun Cinsel Eğitimine İlişkin Görüşleri”. Abant İzzet Baysal Üniversitesi Eğitim Fakültesi Dergisi 18 /3 (2018), 1554-1570. https://doi.org/10.17240/aibuefd.2018.18.39790-471147

Kentler, Helmut. Çocuğuma Nasıl Cinsel Eğitim Verebilirim? çev. Gülderen Pamir. İstanbul: Turkuaz Yayınları. 2. Basım, 2008.

Koç, Ahmet. “Kur'an Kurslarında Eğitim ve Verimlilik Üzerine Bir Araştırma (Tespitler-Öneriler)”. Etkili Din Öğretimi. İstanbul: TIDEF Yayınları, 3. Basım 2010, 512-513. 
Korkmaz, Mehmet. “Öğretici Görüşlerine Göre Yaz Kur'an Kurslarının Sorunları (Kayseri Örneği).” Bilimname 21/2 (2011), 129-158.

Korkmaz, Mehmet. “Kur’an Kurslarında Din Eğitimi ve Sorunları”, ed. Mustafa Köylü, Türkiye'de Din Eğitimi ve Sorunları. İstanbul: Dem Yayınları, 2018. 319-368. https://doi.org/10.17335/ sakaifd.559495

Korkmaz, Mehmet. 4-6 Yaş Kur'an Kurslarında Din Eğitimi (Sorunlar ve Çözüm Önerileri). Kayseri: Kimlik Yayınları, 2019.

Korkmaz, Mehmet. Kur’an Kursu Öğreticilerinin Eğitim-Öğretim Yeterlikleri. DỉB Yayınları. Ankara: 2012. https://doi.org/10.29288/ilted.679601

Kürek, Emine. Cinsel Kimlik Gelişiminde Din Eğitiminin Rolü. Samsun: Ondokuz Mayıs Üniversitesi, Sosyal Bilimler Enstitüsü, Yüksek Lisans Tezi, 2012.

Ogelman, Hülya Gülay - Sarıkaya, Hatice. "Okul öncesi eğitimi öğretmenlerinin değerler eğitimi konusundaki görüşleri: Denizli İli örneği". Sakarya Üniversitesi Eğitim Fakültesi Dergisi 29 (2015), 81-100. https://doi.org/10.17240/aibuefd.2018..-400744

Özaslan, Hatice - Gültekin Akduman, Gülümser. “Ailelerin Mahremiyet Eğitimine İlişkin Görüşlerinin İncelenmesi". ISAS2018-Winter - 2nd International Symposium on Innovative Approaches in Scientific Studies, Samsun, Turkey, November 30-December 2 2018. ed. Turgut Özseven - Volkan Karaca. 3/1363-1369. (Samsun: SETSCI Conferans Indexing System, 2018).

Özdemir, Şuayip - Kavak, Rahime. "Öğretici Görüşlerine Göre Yaz Kur'an Kursları (Elâzı̆̆ Örneği)". Uluslararası Sosyal Araştırmalar Dergisi 4/18 (2011), 298-315.

Patton, Micheal Quinn. Qualitative Research And Evaluation Methods. London: Sage Publication, 3. Edition, 2002.

Reiss, Michael J. "Food, Smoking and Sex: Values in Health Education", Values in Education and Education in Values. ed. J.Mark Halstead and Monica J.Taylor, London: Routledge, 2005.

Samur, Ayşe Öztürk. Değerler Eğitimi Programının 6 Yaş Çocuklarının Sosyal ve Duygusal Gelişimlerine Etkisi. Konya: Selçuk Üniversitesi, Sosyal Bilimler Enstitüsü, Doktora Tezi, 2011. https://doi. org/10.5578/keg.6986

Tavukçuoğlu, Mustafa. “Okulöncesi çocuğunun eğitiminde din duygusu ve din eğitimi”. Selçuk Üniversitesi İlahiyat Fakültesi Dergisi 14 (2002), 51-63. https://doi.org/10.1501/ilhfak_0000000190

TDK Güncel Türkçe Sözlük. Erişim 17 Mayıs 2020. https://sozluk.gov.tr/?kelime=

Tunçeli, Hilal İlknur - Zembat, Rengin. "Erken Çocukluk Döneminde Gelişimin Değerlendirilmesi ve Önemi”. Eğitim Kuram ve Uygulama Araştırmaları Dergisi 3/3 (2017), 112.

Türkyılmaz, Zeynep. 3-6 Yaş Grubu Çocuğu Olan Ebeveynlerin Mahremiyet Eğitimine Dair Bilgilerinin İncelenmesi (Üsküdar Örneği). İstanbul: Üsküdar Üniversitesi, Sağlık Bilimleri Enstitüsü, Yüksek Lisans Tezi, 2019.

Ünal, Feyza. Çocuk Cinsel İstismarında Cinsel Kimlik ve Mahremiyet Eğitiminde Rehberlik Öğretmenlerinin Rolü. Yalova: Yalova Üniversitesi, Sosyal Bilimler Enstitüsü, Yüksek Lisans Tezi, 2019. 
World Health Organization (WHO). "Sexual health, human rights and the law”. Erişim 19 Mayıs 2020. https://apps.who.int/iris/bitstream/handle/10665/175556/9789241564984_eng. pdf; jsessionid=066FA8AC1D5D4421B023452CB8D17636?sequence=1

Yazıbaşı, Muhammed Ali. "Kur’an Kursu Öğreticilerine Göre 4-6 Yaş Kur’an Kursu Öğreticisi, Öğrencisi ve Öğrenci Velisinin İhtiyaç ve Beklentileri Kırıkkale Örneği". Dini Araştırmalar Dergisi 23/57 (Haziran 2020), 95-116. https://doi.org/10.15745/da.749609

Yıldırım, Ali - Şimşek, Hasan. Sosyal Bilimlerde Nitel Araştırma Yöntemleri. Ankara: Seçkin Yayıncılık, 5. Basım 2005. 